\title{
Injuries in Netball-A Systematic Review
}

\author{
Christopher Downs ${ }^{1,2}$, Suzanne J. Snodgrass ${ }^{1,2}$ (D) Ishanka Weerasekara ${ }^{1,3}$ (D) Sarah R. Valkenborghs ${ }^{2,4}$ (D) and
}

Robin Callister ${ }^{2,4^{*}}$ (D)

\begin{abstract}
Background: Netball is estimated to be played by more than 20 million people worldwide, but there is evidence of high injury incidence. A thorough understanding of the types and rates of netball injuries is essential for effective injury management and prevention strategies to be developed and implemented. This systematic review summarises the published findings with respect to injury types, participant characteristics and any identified risk factors for netball injuries.
\end{abstract}

Methods: A librarian-assisted computer search of seven scientific databases was conducted for studies reporting on netball injuries. Inclusion criteria were studies published in English, in peer-reviewed journals, which reported data on injuries and variables (e.g. age and competition level) that have been proposed as possibly associated with netball injury risk.

Results: Forty-six studies (43.5\% prospective, 37\% hospital/insurance records, 19.5\% retrospective) from 45 articles were included after screening. The majority of studies (74\%) were conducted in Australia or New Zealand. There was little consistency in the definition of 'injury'. Elite or sub-elite level players were included in $69 \%$ of studies where the level of competition was reported. The duration of injury surveillance was generally related to the format of competition from which data were collected. Self-report questionnaires were used in $48 \%$ of studies and only $26 \%$ of studies used qualified health professionals to collect data courtside. Injuries to the ankle and knee were the most common (in 19 studies) although the incidence varied considerably across the studies (ankle 13-84\% and knee $8-50 \%$ of injuries). Prevention of ankle and knee injuries should be a priority. Children sustained more upper limb injuries (e.g. fractures) compared with adults who sustained more lower limb injuries (e.g. ankle and knee sprains/strains). A large number of potential risk factors for injury in netball have been investigated in small numbers of studies. The main circumstances of injury are landings, collisions and falls.

Conclusion: Further studies should be directed towards recreational netball, reporting on injury incidence in players by age and utilising high-quality, standardised methods and criteria. Specific injury diagnosis and a better understanding of the circumstances and mechanisms of injury would provide more meaningful data for developing prevention strategies.

Keywords: Netball, Injuries, Systematic review, Epidemiology, Sport, Ankle injuries, Knee injuries

\footnotetext{
* Correspondence: Robin.Callister@newcastle.edu.au

${ }^{2}$ Priority Research Centre for Physical Activity and Nutrition, University of

Newcastle, Newcastle, NSW, Australia

${ }^{4}$ University of Newcastle, School of Biomedical Science and Pharmacy,

Newcastle, NSW, Australia

Full list of author information is available at the end of the article
}

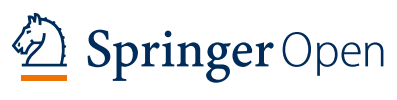

(c) The Author(s). 2021 Open Access This article is licensed under a Creative Commons Attribution 4.0 International License, which permits use, sharing, adaptation, distribution and reproduction in any medium or format, as long as you give appropriate credit to the original author(s) and the source, provide a link to the Creative Commons licence, and indicate if changes were made. The images or other third party material in this article are included in the article's Creative Commons licence, unless indicated otherwise in a credit line to the material. If material is not included in the article's Creative Commons licence and your intended use is not permitted by statutory regulation or exceeds the permitted use, you will need to obtain permission directly from the copyright holder. To view a copy of this licence, visit http://creativecommons.org/licenses/by/4.0/. 


\section{Key Points}

- Injury rates increase with increasing age, and the most common sites of injury change from the upper limb (including fractures to the arm, wrist and hand) in those $<16$ years to the lower limb (particularly ankle and knee sprains and strains) in adults.

- Existing evidence suggests that injury rates appear higher in elite players $(19.35 / 1000 \mathrm{PH})$ than recreational players $(11.3-14 / 1000 \mathrm{PH})$ and in matches than in training.

- Common circumstances of injury are jump-landing, trips/slips/falls and contact with another player or the ball.

- More centralised national databases incorporating quality injury diagnosis across all competition levels would improve our understanding of injuries in netball.

\section{Introduction}

The International Netball Federation (INF) has estimated that more than 20 million people play netball in more than 70 countries [1]. Netball is played predominantly in British Commonwealth countries and usually by females, although there is growing participation by males in both male and mixed competitions [2]. Players typically range in age from 5 to over 50 years and games are played on both indoor and outdoor courts, with a variety of court surfaces [3].

While netball is a sport with one of the highest participation rates, there is also evidence of high injury rates, with comparisons being made to other team sports including all football codes, basketball, field hockey and cricket [4-9]. Injuries are a concern in netball and injury prevention is a goal of the sport's governing bodies (INF; Netball Australia [10]). Injury surveillance is the first stage of the Translating Research into Injury Prevention Practice framework (TRIPP) [11]. Surprisingly there has been no published review synthesising the available data on netball injuries alone. A thorough understanding of the types and rates of netball injuries is essential in order to develop appropriate injury prevention and management strategies. Therefore, the purpose of this systematic review is to identify, collect and synthesise all the published data on netball injuries with respect to injury types, participant characteristics and any identified factors associated with the risk of injuries in netball.

\section{Methods}

The conduct and reporting of this review adheres to PRISMA guidelines [12].

\section{Study Eligibility Criteria}

Studies were included if they reported data on netball injuries sustained by netball players of any age, sex or competition level, were full-text peer-reviewed articles and published in English. Included study designs were observational and experimental. Case studies, reviews and conference abstracts were excluded. Included studies reported data on netball injuries in general and/or in relation to variables such as age, competition level or any other factors associated with netball injury or injury risk. Studies were included regardless of injury definition; i.e. any injury definition was acceptable provided the injury was related to netball matches or training.

\section{Search Strategy}

A biomedical librarian assisted with the development of the search strategy for a systematic search of the electronic databases Cinahl, Medline, Embase, Cochrane, Informit Health, Scopus and SPORTDiscus from 1985 to 20th January 2020 (completed on 20th January 2020). The search was limited to 1985 as the paper by Hopper [13] is regarded as the first peer-reviewed publication of a study of netball injuries. In an effort to be as comprehensive as possible, the search strategy used only the terms Netball* AND Injur*. A secondary search of the reference lists of included papers was conducted to identify additional articles for possible inclusion.

\section{Study Selection and Quality Assessment}

After removal of duplicates, two reviewers independently screened titles and abstracts. If there was uncertainty regarding inclusion of identified articles, the full text was obtained and screened. Discrepancies were first independently re-assessed by each reviewer, then resolved following independent assessment by a third reviewer. Agreement between reviewers was calculated using Cohen's Kappa [14]. The quality of the studies was assessed using the NIH Quality Assessment Tool for Observational Cohort and Cross-Sectional Studies [15].

\section{Data Extraction and Synthesis}

Data from the included studies were extracted by one reviewer and verified by a second in a database template. Data included quality assessment information, country of origin, participant characteristics (age, competition level), data collection period and methods, injury definition, player exposure, injury rate or proportion, injury site, type and severity and key study findings. Results of studies were summarised qualitatively for comparison. Quantitative assessment was limited to tallying the number of studies reporting a particular issue. 


\section{Results}

\section{Study Selection}

The search identified 434 articles after duplicates were removed. After screening, 45 articles were included in the review (Fig. 1). The inter-reviewer agreement for the title/abstract and full-text screenings was considered to be good $(\kappa=0.59,95 \% \mathrm{CI}: 0.51-0.68)$ and very good $(\kappa$ $=0.87$, 95\% CI: 0.74-1.01), respectively. The main reasons for exclusion were that no injury data were reported or publication was not peer-reviewed. Only two articles [13, 16] were published between 1985 and 1989, with 11 in the 1990s, 14 in the 2000s, and 18 in the 2010s. One article [17] reported on two studies (one prospective, one retrospective); therefore, there were 46 studies. Langeveld et al. [18] and Coetzee et al. [19] used data from the same multiday tournament study. Hopper and Elliot [17] and Hopper [20] also used the same data source as one another but they reported on different research aims. There was overlap in the data used in Stevenson et al. [21] (one season) and Finch et al. [22] (two seasons). Also, there was an overlap in the data used in the articles of Hume [23] and Hume and Marshall [24].

\section{Publication Quality}

All studies included in this review had a clearly stated research question or objective (Fig. 2) and most of the studies (96\%) clearly defined their study population. The participation rate of eligible players was adequate (i.e. > $50 \%$ ) in $71 \%$ of studies. The time frame of exposure to netball was reported in $84 \%$ of studies. Sample size justification was reported in only $49 \%$ of studies. Exposure levels were clearly defined and determined using valid and reliable methods in $20 \%$, but only reported in $18 \%$ of studies. Statistical adjustment (e.g. regression) for

Records identified through CINAHL, Medline, EMBASE, COCHRANE LIBRARY, INFORMIT HEALTH, SCOPUS, SPORT DISCUS databases $(n=802)$

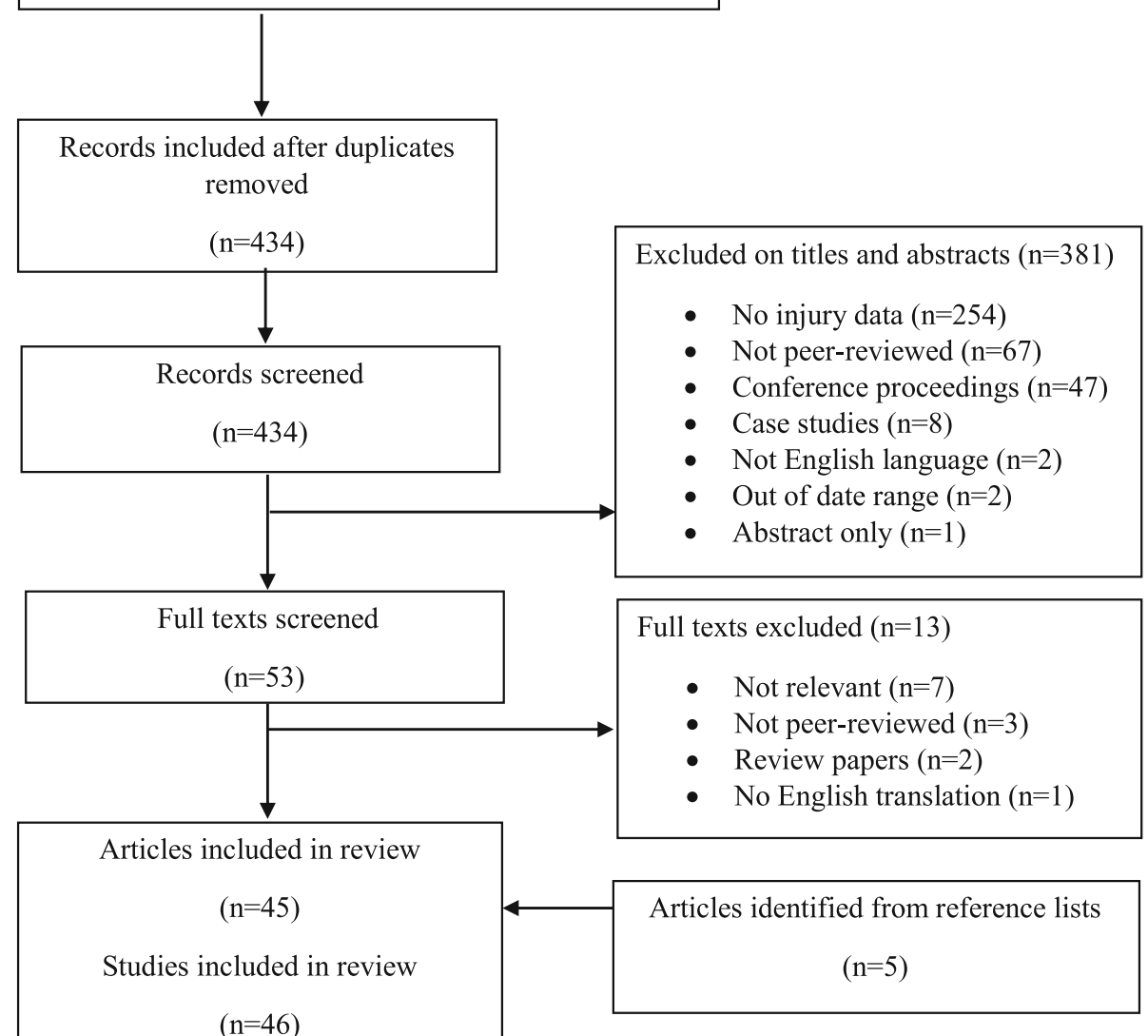

$$
(n=46)
$$

Fig. 1 Search results and selection of studies 


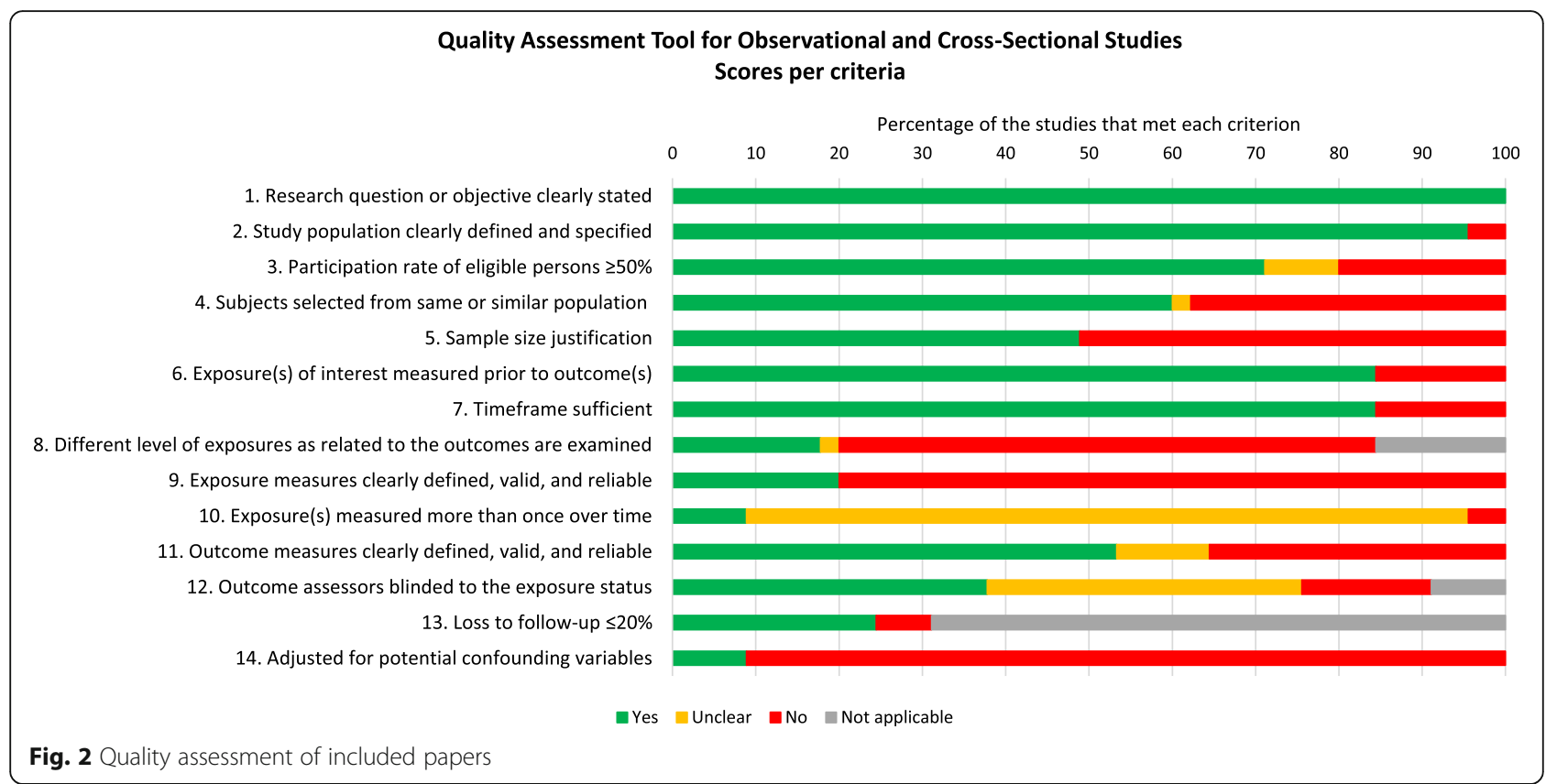

confounding variables (e.g. playing and training time) was adequate in only $9 \%$ of studies. The quality assessment results per individual study and criterion are detailed in Supplemental Table 1.

\section{Review Findings}

Table 1 provides a summary of country of origin, sample size, participant age, competition level, and the type, duration and methods of data collection in the included studies.

\section{Country of Origin of Study}

Of the 46 studies, all were conducted in British Commonwealth countries with 26 (57\%) in Australia, 8 (17\%) in New Zealand, 5 (11\%) in South Africa, 3 (6.5\%) in the UK, 2 (4.3\%) in Malaysia and 1 (2.2\%) each in Singapore and Jamaica.

\section{Study Categories}

The studies are presented in Table 1 in four categories: prospective studies over one or more playing seasons $(n$ $=14,30 \%)$, prospective studies at tournaments $(n=6$, $13.0 \%)$, retrospective studies $(n=9,20 \%)$ and studies accessing database sources, including hospital and insurance company records $(n=17,37 \%)$. One article [17] reported both prospective and retrospective studies and the findings from these data are reported in their respective sections.

\section{Number of Participants and Injuries}

Among prospective studies during competition seasons, participant numbers ranged from 17 to 11,228 , with $50 \%$
( $n=7)$ of studies having < 100 participants. Injury numbers ranged from 11 to 608 , with $43 \%(n=6)$ reporting $<25$ injuries. In prospective studies over the course of a tournament, participant numbers ranged from 192 to 1280 , and injury numbers from 52 to 205 . In the retrospective studies, participant numbers ranged from 16 to 1084; $88 \%(n=7)$ of studies had $<254$ participants. Injury numbers ranged from 16 to 504 with most studies reporting $<100$ injuries. Injury numbers in the hospital, clinic and insurance records studies ranged from 3 to 5 , 263 with nine of the studies reporting $>1000$ injuries.

\section{Age of Participants}

Age range or mean age were reported in most studies. Among the prospective studies, only Pringle et al. [34] focused on children $<16$ years, whereas many studies $[13,17,20,28,29,36]$ included participants $>12$ years old, with the mean age typically in the 20-25-year range. In the retrospective studies, Smith et al. [43] included only those 6-16 years and Whatman and Reid [45] investigated secondary school participants $(16 \pm 1$ years $)$ whereas the other studies covered wider age ranges [45]. Hassan et al. [50] in their hospital ED admission study focused on children 5-15 years whereas the other large database reports included both children and adults. However, these studies limited their reporting of results related to age $[3,9,17,42,48,54,55]$ to only 'child versus adult' limiting the extraction of injury by specific age brackets. Although some studies did not report age specifically, it was inferred from the level of competition, which was often played in age categories in those studies. 
Table 1 Characteristics of included studies $(n=46)$ documenting injuries to netball players

\begin{tabular}{|c|c|c|c|c|c|c|c|}
\hline Study & $\begin{array}{l}\text { Country } \\
\text { of origin }\end{array}$ & Sample & $\begin{array}{l}\text { Age } \\
\text { (years) } \\
\text { Mean } \pm \\
\text { SD or } \\
\text { range }\end{array}$ & $\begin{array}{l}\text { Competition } \\
\text { level }\end{array}$ & $\begin{array}{l}\text { Data collection } \\
\text { period }\end{array}$ & Data collection methods & $\begin{array}{l}\text { Injury data } \\
\text { collected }\end{array}$ \\
\hline
\end{tabular}

\section{Prospective season competition}

et al. 2017 [25]

\begin{tabular}{|c|c|}
\hline $\begin{array}{l}\text { Elphinston } \\
\text { et al. } 2006 \text { [26] }\end{array}$ & UK \\
\hline $\begin{array}{l}\text { Ferreira et al. } \\
2010 \text { [27] }\end{array}$ & SA \\
\hline $\begin{array}{l}\text { Finch et al. } \\
2002 \text { [22] }\end{array}$ & AUS \\
\hline
\end{tabular}

94 participants $21.5 \pm \quad$ Elite/Inter-

11 ankle 6.3 district

injuries recreational

(club)

$2002[22]$

Hopper 1986 AUS

[13]

Hopper et al. AUS

1995 [28]

17 participants $25.9 \pm \quad$ Elite

22 vs 4 injuries 2.6

25 participants 18-23 Elite

46 injuries

247

participants

216 netball

injuries

3108

participants

158 netball

injuries

11228

participants

608 netball

injuries

Hopper et al. AUS

1995 [29]

72 participants

22 netball

injuries

$\sim 22 \pm \quad$ Recreational

$\begin{array}{ll}\sim 22 \pm & \text { (club) }\end{array}$

\section{sons per player}

to

Recreational

(club)

$>14$ Competitive

$18.8 \pm$ to

Recreational

(club)

$15-36$

Elite to

Recreational

(club)

season

1989

$\times 14$-week

season

1983

$5 \times 14$-week

seasons

1984-1989

14-week

\begin{tabular}{|c|c|c|c|c|c|}
\hline $\begin{array}{l}\text { Maulder et al. } \\
2013 \text { [30] }\end{array}$ & SA & $\begin{array}{l}24 \text { participants } \\
9 \text { netball } \\
\text { injuries }\end{array}$ & $\begin{array}{l}21.6 \pm \\
3.2\end{array}$ & $\begin{array}{l}\text { Elite (national) } \\
\text { Sub-elite } \\
\text { (regional) }\end{array}$ & $\begin{array}{l}1 \times 6 \text {-month } \\
\text { season }\end{array}$ \\
\hline $\begin{array}{l}\text { Mckay et al. } \\
1996 \text { [31] }\end{array}$ & AUS & $\begin{array}{l}9,190 \\
\text { participants } \\
159 \text { netball } \\
\text { injuries }\end{array}$ & $\begin{array}{l}27.2 \pm \\
7.8\end{array}$ & $\begin{array}{l}\text { Elite/ } \\
\text { Recreational } \\
\text { (club) }\end{array}$ & $\begin{array}{l}2 \times \text { seasons } \\
1991-1992\end{array}$ \\
\hline $\begin{array}{l}\text { McManus } \\
\text { et al. } 2006 \text { [32] }\end{array}$ & AUS & $\begin{array}{l}368 \\
\text { participants } \\
272 \text { netball } \\
\text { injuries }\end{array}$ & $\begin{array}{l}\text { Majority } \\
(66 \%) \\
16-30\end{array}$ & $\begin{array}{l}\text { Recreational } \\
\text { (club) }\end{array}$ & $\begin{array}{l}2 \times \text { seasons } \\
1997-1998\end{array}$ \\
\hline $\begin{array}{l}\text { Pickering } \\
\text { Rodriguez } \\
\text { et al. } 2017 \text { [33] }\end{array}$ & AUS/NZ & $\begin{array}{l}29 \text { participants } \\
12 \text { lower body } \\
\text { netball injuries }\end{array}$ & $\begin{array}{l}24.1 \pm \\
3.2\end{array}$ & Elite/Sub-elite & $\begin{array}{l}1 \times \text { season } \\
2013\end{array}$ \\
\hline $\begin{array}{l}\text { Pringle et al. } \\
1998 \text { [34] }\end{array}$ & $\mathrm{NZ}$ & $\begin{array}{l}1512 \\
\text { participants } \\
15 \text { netball } \\
\text { injuries }\end{array}$ & $6-15$ & $\begin{array}{l}\text { Recreational } \\
\text { (club) }\end{array}$ & 4 weeks of season \\
\hline $\begin{array}{l}\text { Stevenson } \\
\text { et al. } 2000 \text { [21] }\end{array}$ & AUS & $\begin{array}{l}258 \\
\text { participants } \\
112 \text { netball } \\
\text { injuries }\end{array}$ & $\begin{array}{l}22 \pm 8 \\
(13.6- \\
30.4)\end{array}$ & $\begin{array}{l}\text { Recreational } \\
\text { (club) }\end{array}$ & $\begin{array}{l}1 \times 5 \text {-month sea- } \\
\text { son } 1997\end{array}$ \\
\hline $\begin{array}{l}\text { Zulkarnain } \\
\text { et al. } 2019 \text { [35] }\end{array}$ & Malaysia & $\begin{array}{l}42 \text { participants } \\
\text { Intervention } \\
(\mathrm{IG}) n=17 \\
\text { Control (CG) } n \\
=25\end{array}$ & $\begin{array}{l}\text { IG } 21 . \pm \\
21.8 \\
\text { CG } 20.9 \\
\pm 1.9\end{array}$ & $\begin{array}{l}\text { Club/District } \\
23.9 \% \\
\text { State } 60.9 \% \\
\text { National } \\
15.2 \%\end{array}$ & $\begin{array}{l}6 \text { weeks post } \\
\text { intervention }\end{array}$ \\
\hline
\end{tabular}

Prospective tournaments

\begin{tabular}{|c|c|c|c|c|c|}
\hline $\begin{array}{l}\text { Hopper and } \\
\text { Elliot } 1993 \text { [17] }\end{array}$ & AUS & $\begin{array}{l}228 \\
\text { participants } \\
52 \text { netball } \\
\text { injuries }\end{array}$ & $\begin{array}{l}\text { U16 } 14.8 \\
\pm 0.4 \\
\text { U21 } 19.2 \\
\pm 2.2 \\
\text { Open } \\
23.7 \pm 3.6\end{array}$ & Elite/Sub-elite & $\begin{array}{l}\text { Multi-day } \\
\text { Tournament } \\
1988\end{array}$ \\
\hline
\end{tabular}

Elite/Inter-district reports (injury/exposure) by team physio/ Ankle only club director; Recreational self-report; Follow-up by phone; Preseason data collection in one session.

Physiotherapy assessment.

All injuries

Weekly physiotherapy clinic assessment.

All injuries

Baseline questionnaire; diary record then self-report by monthly telephone interview over each season.

All injuries

Injury data recorded in questionnaire by courtside first aid room physiotherapist; other data provided by player in

self-report questionnaire.

All moderate

to severe

injuries

Injury data recorded in questionnaire by courtside first aid room physiotherapist; other data provided by player in

self-report questionnaire.

All moderate to severe

injuries

Preseason lab testing: somatotype, hypermobility, vertical jump, anaerobic fitness (10-s cycle).

njury data recorded in questionnaire by courtside first aid room physiotherapist; other data provided by player in self-report questionnaire; training injuries by player report to physiotherapist.

Player self-report fortnightly via email/phone questioning Lower limb dominance and asymmetry assessments

during preseason.

Courtside injury observers (physiotherapy students/St John's Ambulance First Aiders) Questionnaire completed by players; Phone follow-up to obtain treatment sought and time loss.

Baseline questionnaire then telephone interviews every 4 weeks throughout season.

Injuries: Elite-team physiotherapist; Sub-elite—self-report. Preseason lower limb stiffness measures.

Trained observers (physiotherapy or sports science students) observed games and recorded injuries on incident form over 4 weeks; Post-game interview with player; Telephone follow-up by physiotherapist within 3 days and then after one week (diagnosis and time loss).

Baseline questionnaire then telephone interviews every $4 \quad$ All injuries weeks throughout season.

Study compared 6-week safe-landing technique injury prevention program (Down 2 Earth) to standard training program; injuries recorded for 6 weeks following the intervention period.

Player baseline questionnaire and podiatric assessment of lower limbs and back. Injuries assessed and recorded by physiotherapists; players injuries only completed questionnaire regarding events relating to the injury.
Lower body

non-contact injuries

ower limb and back

Lower limb and back only

All injuries

Lower limb injuries 
Table 1 Characteristics of included studies $(n=46)$ documenting injuries to netball players (Continued)

\begin{tabular}{|c|c|c|c|c|c|c|c|}
\hline Study & $\begin{array}{l}\text { Country } \\
\text { of origin }\end{array}$ & Sample & $\begin{array}{l}\text { Age } \\
\text { (years) } \\
\text { Mean } \pm \\
\text { SD or } \\
\text { range }\end{array}$ & $\begin{array}{l}\text { Competition } \\
\text { level }\end{array}$ & $\begin{array}{l}\text { Data collection } \\
\text { period }\end{array}$ & Data collection methods & $\begin{array}{l}\text { Injury data } \\
\text { collected }\end{array}$ \\
\hline $\begin{array}{l}\text { Hopper } 1997 \\
\text { [20] }\end{array}$ & AUS & $\begin{array}{l}213 \\
\text { participants } \\
52 \text { netball } \\
\text { injuries }\end{array}$ & $\begin{array}{l}\text { U16 } 14.8 \\
\pm 0.4 \\
\text { U21 } 19.2 \\
\pm 2.2 \\
\text { Open } \\
23.7 \pm 3.6\end{array}$ & Elite/Sub-elite & $\begin{array}{l}\text { Multi-day } \\
\text { Tournament } \\
1988\end{array}$ & $\begin{array}{l}\text { Player baseline questionnaire and podiatric assessment of } \\
\text { lower limbs and back. } \\
\text { Injuries assessed and recorded by physiotherapists; players } \\
\text { completed questionnaire regarding events relating to the } \\
\text { injury; somatotype assessed. }\end{array}$ & $\begin{array}{l}\text { Lower limb } \\
\text { and back } \\
\text { injuries only }\end{array}$ \\
\hline $\begin{array}{l}\text { Hume et al. } \\
2000[36]\end{array}$ & AUS & $\begin{array}{l}940 \\
\text { participants } \\
131 \text { netball } \\
\text { injuries }\end{array}$ & $\begin{array}{l}18.4 \pm \\
4.4 \\
\text { U17, } \\
\text { U19, } \\
\text { U23, } \\
\text { Open }\end{array}$ & Sub-elite & $\begin{array}{l}\text { Multi-day } \\
\text { Tournament } \\
\text { (State) }\end{array}$ & $\begin{array}{l}\text { Injured players completed a 5-page questionnaire; Injury } \\
\text { treatment provided by physiotherapists, sports trainers, St } \\
\text { John's First Aid personnel, Sports Medicine Australia Van } \\
\text { personnel, coaches, or self-treatment. }\end{array}$ & All injuries \\
\hline $\begin{array}{l}\text { Langeveld } \\
\text { et al. } 2012 \text { [18] }\end{array}$ & SA & $\begin{array}{l}1280 \\
\text { participants } \\
205 \text { netball } \\
\text { injuries to } 192 \\
\text { players }\end{array}$ & $\begin{array}{l}\text { U19, } \\
\text { U21, } \\
\text { Open, } \\
\text { USSA }\end{array}$ & Elite/Sub-elite & $\begin{array}{l}3 \times \text { Multi-day } \\
\text { Tournaments } \\
2009\end{array}$ & $\begin{array}{l}\text { Injury questionnaire completed by specifically-trained med- } \\
\text { ical staff, team managers or coaches. }\end{array}$ & All injuries \\
\hline $\begin{array}{l}\text { Coetzee et al. } \\
2014[19]\end{array}$ & SA & $\begin{array}{l}1280 \\
\text { participants } \\
205 \text { netball } \\
\text { injuries to } 192 \\
\text { players }\end{array}$ & $\begin{array}{l}\text { U19, } \\
\text { U21, } \\
\text { Open, } \\
\text { USSA }\end{array}$ & Elite/Sub-elite & $\begin{array}{l}3 \times \text { Multi-day } \\
\text { Tournaments } \\
2009\end{array}$ & $\begin{array}{l}\text { Injury questionnaire completed by specifically-trained med- } \\
\text { ical staff, team managers or coaches and questionnaire } \\
\text { completed by players re training history and injury preven- } \\
\text { tion practices. }\end{array}$ & All injuries \\
\hline $\begin{array}{l}\text { Smyth et al. } \\
2019 \text { [37] }\end{array}$ & AUS & $\begin{array}{l}192 \\
\text { participants } \\
103 \text { injuries to } \\
80 \text { players }\end{array}$ & $\begin{array}{l}\text { U17 } \\
\text { U19 }\end{array}$ & Pre-elite & $\begin{array}{l}\text { 6 Day Tournament } \\
2018\end{array}$ & $\begin{array}{l}\text { Medical attention injuries diagnosed by physiotherapists } \\
\text { and recorded whether the athlete could continue to play } \\
\text { immediately after the injury. Players completed a Health } \\
\text { Problems Questionnaire which provided additional } \\
\text { indications of injuries and effects. }\end{array}$ & All injuries \\
\hline \multicolumn{8}{|l|}{ Retrospective } \\
\hline $\begin{array}{l}\text { Attenborough } \\
\text { et al. } 2016 \text { [38] }\end{array}$ & AUS & $\begin{array}{l}96 \text { participants } \\
69 \text { previous } \\
\text { ankle injuries }\end{array}$ & $\begin{array}{l}\text { ID } 19.4 \\
\pm 3.5 \\
\text { Club } \\
24.1 \pm \\
7.9\end{array}$ & $\begin{array}{l}\text { Inter-district/ } \\
\text { Recreational } \\
\text { (club) }\end{array}$ & $\begin{array}{l}\text { All previous ankle } \\
\text { injuries }\end{array}$ & $\begin{array}{l}\text { Participant questionnaire including ankle sprain history; } \\
\text { assessment with Cumberland Ankle Instability Tool_Youth } \\
\text { and ankle joint laxity (arthrometer). }\end{array}$ & $\begin{array}{l}\text { Recurrent } \\
\text { ankle injuries }\end{array}$ \\
\hline $\begin{array}{l}\text { Finch et al. } \\
2006 \text { [39] }\end{array}$ & AUS & $\begin{array}{l}1084 \text { residents } \\
648 \text { all sports/ } \\
\text { activities } 34 \\
\text { netball injuries }\end{array}$ & $\geq 5$ & Recreational & $\begin{array}{l}\text { All sport or active } \\
\text { recreation injuries } \\
\text { in previous } 2 \text { weeks }\end{array}$ & Household telephone survey. & All injuries \\
\hline $\begin{array}{l}\text { Hopper and } \\
\text { Elliot } 1993[17]\end{array}$ & AUS & $\begin{array}{l}228 \\
\text { participants } \\
504 \text { netball } \\
\text { injuries }\end{array}$ & $\begin{array}{l}\text { U16 } 14.8 \\
\pm 0.4 \\
\text { U21 } 19.2 \\
\pm 2.2 \\
\text { Open } \\
23.7 \pm 3.6\end{array}$ & Elite/Sub-elite & $\begin{array}{l}\text { All previous lower } \\
\text { limb and back } \\
\text { injuries }\end{array}$ & $\begin{array}{l}\text { Questionnaire: injury history, age, playing position, playing } \\
\text { experience, use of orthosis, perceived reasons for injury } \\
\text { Podiatric assessments of lower limb and back, including } \\
\text { foot type. }\end{array}$ & $\begin{array}{l}\text { Lower limb } \\
\text { and back } \\
\text { injuries }\end{array}$ \\
\hline $\begin{array}{l}\text { Hopper et al. } \\
1994[40]\end{array}$ & AUS & $\begin{array}{l}204 \\
\text { participants } \\
188 \text { injured } \\
\text { players } \\
449 \text { lower limb } \\
\text { injuries }\end{array}$ & $\begin{array}{l}\text { U16 } 14.8 \\
\pm N R \\
\text { U21 } 19.1 \\
\pm N R \\
\text { Open } \\
23.7 \pm \\
\text { NR }\end{array}$ & Elite/Sub-elite & $\begin{array}{l}\text { All previous lower } \\
\text { limb injuries }\end{array}$ & $\begin{array}{l}\text { Questionnaire and foot assessments as per Hopper et al. } \\
\text { 1993. } 5 \text { categories of foot types: normal, pronating with } \\
\text { rearfoot abnormalities, pronating with forefoot } \\
\text { abnormalities, non-pronating, other. }\end{array}$ & $\begin{array}{l}\text { Lower limb } \\
\text { injuries }\end{array}$ \\
\hline $\begin{array}{l}\text { Pillay et al. } \\
2012 \text { [41] }\end{array}$ & SA & $\begin{array}{l}254 \\
\text { participants } \\
301 \text { netball } \\
\text { injuries } \\
157 \text { players } \\
\text { injured }\end{array}$ & $\begin{array}{l}\text { Nat } 24.3 \\
\pm 6.3 \\
\text { State } \\
23.9 \pm \\
5.1 \\
\text { Club } \\
24.2 \pm \\
4.3\end{array}$ & Elite/Sub elite & $\begin{array}{l}\text { All injuries in } \\
\text { previous season }\end{array}$ & Questionnaire completed by netball players at tournament. & All injuries \\
\hline $\begin{array}{l}\text { Singh et al. } \\
2013[42]\end{array}$ & Jamaica & $\begin{array}{l}59 \text { participants } \\
70 \text { netball } \\
\text { injuries }\end{array}$ & $\begin{array}{l}\text { U16, } \\
\text { U21, } \\
\text { Senior }\end{array}$ & Elite & All previous injuries & $\begin{array}{l}\text { Questionnaire-self-reported player characteristics, injuries, } \\
\text { factors associated with injury. }\end{array}$ & All injuries \\
\hline $\begin{array}{l}\text { Smith et al. } \\
2005 \text { [43] }\end{array}$ & AUS & $\begin{array}{l}200 \\
\text { participants } \\
69 \text { players } \\
\text { injured }\end{array}$ & $\begin{array}{l}6-16 \\
11 \pm 2.5\end{array}$ & $\begin{array}{l}\text { Competitive } \\
\text { to } \\
\text { recreational } \\
\text { (club) }\end{array}$ & All previous injuries & $\begin{array}{l}\text { Questionnaire-self-reported player characteristics, injuries, } \\
\text { preventative equipment use } \\
\text { Joint hypermobility assessed using Beighton index. }\end{array}$ & All injuries \\
\hline
\end{tabular}


Table 1 Characteristics of included studies $(n=46)$ documenting injuries to netball players (Continued)

\begin{tabular}{|c|c|c|c|c|c|c|c|}
\hline Study & $\begin{array}{l}\text { Country } \\
\text { of origin }\end{array}$ & Sample & $\begin{array}{l}\text { Age } \\
\text { (years) } \\
\text { Mean } \pm \\
\text { SD or } \\
\text { range }\end{array}$ & $\begin{array}{l}\text { Competition } \\
\text { level }\end{array}$ & $\begin{array}{l}\text { Data collection } \\
\text { period }\end{array}$ & Data collection methods & $\begin{array}{l}\text { Injury data } \\
\text { collected }\end{array}$ \\
\hline $\begin{array}{l}\text { Stuelcken } \\
\text { et al. } 2016[44]\end{array}$ & AUS & $\begin{array}{l}16 \text { elite players } \\
\text { with } \mathrm{ACL} \\
\text { injuries }\end{array}$ & $\begin{array}{l}\text { Not } \\
\text { reported }\end{array}$ & Elite & Televised games & $\begin{array}{l}\text { Medically diagnosed injury; Video analysis of circumstances } \\
\text { of injury. }\end{array}$ & $\mathrm{ACL}$ injuries \\
\hline $\begin{array}{l}\text { Whatman } \\
\text { et al. } 2017 \text { [45] }\end{array}$ & NZ & $\begin{array}{l}166 \text { female } \\
\text { participants }\end{array}$ & $16 \pm 1$ & $\begin{array}{l}\text { Secondary } \\
\text { school }\end{array}$ & $\begin{array}{l}\text { Overuse knee and } \\
\text { ankle injuries in } \\
\text { previous } 12 \\
\text { months }\end{array}$ & $\begin{array}{l}\text { Oslo Sports Trauma Research Centre Overuse Injury } \\
\text { Questionnaire re knee }(n=106 \text { completed) and ankle ( } n= \\
113 \text { completed). }\end{array}$ & $\begin{array}{l}\text { Knee and } \\
\text { ankle overuse } \\
\text { injuries }\end{array}$ \\
\hline \multicolumn{8}{|c|}{ Hospital, clinic or insurance records } \\
\hline $\begin{array}{l}\text { Cassell et al. } \\
2003[46]\end{array}$ & AUS & $\begin{array}{l}2300 \text { all sports } \\
81 \text { netball to } \\
\text { ED } \\
67 \text { netball to } \\
\text { GP }\end{array}$ & $>4$ & $\begin{array}{l}\text { Mostly } \\
\text { recreational }\end{array}$ & 1 year & $\begin{array}{l}\text { Netball-related ED presentations from Victorian Injury } \\
\text { Surveillance System. } \\
\text { Netball-related GP presentations from Extended Latrobe } \\
\text { Valley Injury Surveillance (ELVIS) project. }\end{array}$ & $\begin{array}{l}\mathrm{ED} \text { and } \mathrm{GP} \\
\text { presentations }\end{array}$ \\
\hline $\begin{array}{l}\text { Chong et al. } \\
2004[47]\end{array}$ & Singapore & $\begin{array}{l}13 \text { female } A C L \\
\text { injuries } \\
4 \text { netball } \\
\text { injuries }\end{array}$ & $13-38$ & School/Club & 4 years & Female $A C L$ injuries at regional Singapore hospital & $\begin{array}{l}\text { Female } A C L \\
\text { injuries }\end{array}$ \\
\hline $\begin{array}{l}\text { Fernando } \\
\text { et al. } 2018 \text { [9] }\end{array}$ & AUS & $\begin{array}{l}5483 \text { netball } \\
\text { injury } \\
\text { presentation } \\
\text { to ED }\end{array}$ & $>5$ & All & $\begin{array}{l}3 \text { years } \\
\text { Mid 2012-Mid } \\
2015\end{array}$ & $\begin{array}{l}\text { Presentations of Victorian Emergency Minimum Dataset in } \\
\text { Victoria NSW. }\end{array}$ & $\begin{array}{l}\text { All } \\
\text { presentations }\end{array}$ \\
\hline $\begin{array}{l}\text { Finch et al. } \\
1998[6]\end{array}$ & AUS & $\begin{array}{l}2,165 \text { child } \\
\text { netball injuries } \\
3,098 \text { adult } \\
\text { netball injuries }\end{array}$ & $\begin{array}{l}<15 \\
\geq 15\end{array}$ & $\begin{array}{l}\text { Mostly } \\
\text { recreational }\end{array}$ & 5 years & $\begin{array}{l}\text { Sport and active recreation injury cases at selected hospital } \\
\text { emergency departments from 1989-1993; standardised } \\
\text { data collection form completed by injured player (age, sex, } \\
\text { sport, context of injury) and treating doctor (diagnosis, } \\
\text { treatment details). }\end{array}$ & $\begin{array}{l}\text { Emergency } \\
\text { department } \\
\text { injury cases }\end{array}$ \\
\hline $\begin{array}{l}\text { Flood et al. } \\
2009[48]\end{array}$ & AUS & $\begin{array}{l}4,596 \text { netball } \\
\text { injuries }\end{array}$ & $\begin{array}{l}\geq 5 \\
26.3 \pm \\
10.9\end{array}$ & All & $\begin{array}{l}5 \text { years } \\
2000-2004\end{array}$ & $\begin{array}{l}\text { Netball-related hospital admissions from the National } \\
\text { Hospital Morbidity Database; includes data from all public } \\
\text { and most private hospitals. }\end{array}$ & $\begin{array}{l}\text { Hospital } \\
\text { admissions }\end{array}$ \\
\hline $\begin{array}{l}\text { Gwynne-Jones } \\
\text { et al. } 2011[49]\end{array}$ & $N Z$ & $\begin{array}{l}363 \text { Achilles } \\
\text { injuries } \\
285 \text { sports } \\
\text { injuries } \\
88 \text { netball } \\
\text { injuries }\end{array}$ & $15-60$ & All & $\begin{array}{l}8.5 \text { years } \\
1999-2008\end{array}$ & $\begin{array}{l}\text { Participants identified through emergency department, in } \\
\text { patient, surgical audit and physiotherapy department } \\
\text { records. }\end{array}$ & $\begin{array}{l}\text { Achilles } \\
\text { tendon } \\
\text { rupture }\end{array}$ \\
\hline $\begin{array}{l}\text { Hassan et al. } \\
2001 \text { [50] }\end{array}$ & UK & $\begin{array}{l}54 \text { netball } \\
\text { injuries } \\
13 \text { netball } \\
\text { fractures }\end{array}$ & $5-15$ & Children & $\begin{array}{l}1 \text { year } \\
1997-1998\end{array}$ & $\begin{array}{l}\text { District General Hospital accident and emergency } \\
\text { department. }\end{array}$ & Fractures \\
\hline $\begin{array}{l}\text { Hon et al. } \\
2001[51]\end{array}$ & Malaysia & $\begin{array}{l}113 \text { sports } \\
\text { injuries } \\
3 \text { netball } \\
\text { injuries }\end{array}$ & $7-59$ & $\begin{array}{l}\text { Competitive/ } \\
\text { recreational }\end{array}$ & $\begin{array}{l}1 \text { year } \\
1998-1999\end{array}$ & $\begin{array}{l}\text { Patients reporting to Department of Orthopaedic and } \\
\text { Traumatology of Seremban Hospital with fractures } \\
\text { sustained during sporting activity. }\end{array}$ & Fractures \\
\hline $\begin{array}{l}\text { Hume } 1993 \\
\text { [23] }\end{array}$ & NZ & $\begin{array}{l}143 \\
\text { hospitalisations } \\
284 \text { netball in } \\
\text { ED } \\
1420 \text { insurance } \\
\text { claims } \\
298 \text { sports } \\
\text { injury clinic }\end{array}$ & $\begin{array}{l}5-15 \\
\geq 15\end{array}$ & All & $\begin{array}{l}\text { Most } 1 \text { year } \\
\text { Clinic } 1.7 \text { years }\end{array}$ & $\begin{array}{l}\text { Multiple sources: hospitalisation morbidity data (1 year); } \\
\text { Dunedin Hospital Emergency (A\&E) Department data ( } 1 \\
\text { year); Accident Compensation Corporation (insurance) } \\
\text { claims ( } 1 \text { year); Dunedin Sports Injury Clinic data ( } 1.7 \text { years). } \\
\text { Population and netball participation data from } \\
\text { government sources. }\end{array}$ & $\begin{array}{l}\text { All } \\
\text { presentations } \\
\text { and claims }\end{array}$ \\
\hline $\begin{array}{l}\text { Hume et al. } \\
1994[24]\end{array}$ & NZ & $\begin{array}{l}139 \\
\text { hospitalisations } \\
\text { No fatal } \\
\text { injuries } \\
3.2 \% \text { of all } \\
\text { injuries } \\
89.3 \text { injuries/ } \\
100,000 \\
1420 \text { Insurance } \\
\text { claims- } \\
\text { netball } 5.3 \% \\
279 \text { ED- } \\
\text { netball } 7.6 \% \\
169 \text { Sports }\end{array}$ & All & All & $\begin{array}{l}\text { Mostly } 1 \text { year } \\
\text { Mortality } 10 \text { years }\end{array}$ & $\begin{array}{l}\text { Multiple sources: HIS mortality data (10 years); } \\
\text { hospitalisation morbidity data ( } 1 \text { year); Dunedin Hospital } \\
\text { Emergency (A\&E) Department data ( } 1 \text { year); Accident } \\
\text { Compensation Corporation (insurance) claims (1 year); } \\
\text { Dunedin Sports Injury Clinic data (1 year). }\end{array}$ & $\begin{array}{l}\text { All } \\
\text { presentations } \\
\text { and claims }\end{array}$ \\
\hline
\end{tabular}


Table 1 Characteristics of included studies $(n=46)$ documenting injuries to netball players (Continued)

\begin{tabular}{|c|c|c|c|c|c|c|c|}
\hline Study & $\begin{array}{l}\text { Country } \\
\text { of origin }\end{array}$ & Sample & $\begin{array}{l}\text { Age } \\
\text { (years) } \\
\text { Mean } \pm \\
\text { SD or } \\
\text { range }\end{array}$ & $\begin{array}{l}\text { Competition } \\
\text { level }\end{array}$ & $\begin{array}{l}\text { Data collection } \\
\text { period }\end{array}$ & Data collection methods & $\begin{array}{l}\text { Injury data } \\
\text { collected }\end{array}$ \\
\hline & & $\begin{array}{l}\text { clinic-netball } \\
27.3 \%\end{array}$ & & & & & \\
\hline $\begin{array}{l}\text { Joseph et al. } \\
2019[3]\end{array}$ & AUS & $\begin{array}{l}1215 \text { approved } \\
\text { insurance } \\
\text { claims }\end{array}$ & $34 \pm 17$ & All & $\begin{array}{l}1 \text { year } \\
2016\end{array}$ & $\begin{array}{l}\text { Netball Australia National Risk Protection Accident } \\
\text { Insurance Program data for 2016. Covers all registered } \\
\text { players in competitions organised by Netball Australia. } \\
\text { Covers training and matches. }\end{array}$ & $\begin{array}{l}\text { All approved } \\
\text { claims }\end{array}$ \\
\hline $\begin{array}{l}\text { King et al. } \\
2019 \text { [52] }\end{array}$ & NZ & $\begin{array}{l}11748 \text { mod- } \\
\text { serious } \\
\text { Females 10, } \\
061 \\
\text { Males } 1687 \\
9 \text { serious } \\
\text { claims (all } \\
\text { female) }\end{array}$ & & All & $\begin{array}{l}5 \text { years } \\
2012-2016\end{array}$ & $\begin{array}{l}\text { NZ Accident Compensation Corporation data over } 5 \text { years } \\
\text { on acute personal injury claims. Data collected in } \\
\text { standardised manner when present to medical } \\
\text { practitioner. }\end{array}$ & $\begin{array}{l}\text { Moderate to } \\
\text { serious and } \\
\text { serious } \\
\text { injuries }\end{array}$ \\
\hline $\begin{array}{l}\text { Kirkwood et al. } \\
2019[8]\end{array}$ & UK & $\begin{array}{l}N=154 \\
\text { netball } \\
\text { attendances } \\
\text { (98\% female) }\end{array}$ & $0-19$ & All & $\begin{array}{l}2.25 \text { years } \\
\text { Jan 2012-Mar } 2014\end{array}$ & Injuries incurred during netball participation. & $\begin{array}{l}\text { All ED } \\
\text { attendances }\end{array}$ \\
\hline $\begin{array}{l}\text { Love et al. } \\
1998[53]\end{array}$ & NZ & $\begin{array}{l}260 \text { netball } \\
\text { dental } \\
\text { insurance } \\
\text { claims }\end{array}$ & $0-75+$ & All & $\begin{array}{l}4 \text { years } \\
1993-1996\end{array}$ & $\begin{array}{l}\text { New Zealand Accident Rehabilitation and Compensation } \\
\text { Insurance Corporation (ACC) database of dental claims } \\
\text { related to sports injuries for } 4 \text { years. }\end{array}$ & Dental claims \\
\hline $\begin{array}{l}\text { Otago et al. } \\
2007[54]\end{array}$ & AUS & $\begin{array}{l}829 \text { netball } \\
\text { injuries }\end{array}$ & $\geq 10$ & All & $\begin{array}{l}1 \text { year } \\
1999\end{array}$ & $\begin{array}{l}\text { Insurance claims (accepted) for netball injuries over } 12 \\
\text { months. }\end{array}$ & $\begin{array}{l}\text { Insurance } \\
\text { claims }\end{array}$ \\
\hline $\begin{array}{l}\text { Purdam } 1987 \\
\text { [16] }\end{array}$ & AUS & $\begin{array}{l}20 \text { Netball } \\
\text { participants } \\
105 \text { netball } \\
\text { injuries }\end{array}$ & $\begin{array}{l}\text { Not } \\
\text { reported }\end{array}$ & Elite & $\begin{array}{l}0.83 \text { year } \\
1986\end{array}$ & $\begin{array}{l}\text { Physiotherapy department records at the Australian } \\
\text { Institute of Sport }\end{array}$ & All treated \\
\hline $\begin{array}{l}\text { Smartt et al. } \\
2009[55]\end{array}$ & NZ & $\begin{array}{l}1126 \text { netball } \\
\text { injuries } \\
\text { Male } 215 \\
\text { Female } 911\end{array}$ & $\begin{array}{l}5-82 \\
29 \pm N R\end{array}$ & All & $\begin{array}{l}6 \text { years } \\
2000-2005\end{array}$ & $\begin{array}{l}\text { Hospital inpatients related to netball injury; data also } \\
\text { linked to injury entitlement claims } \\
\text { Participation in netball estimated from national survey } \\
\text { data. }\end{array}$ & $\begin{array}{l}\text { Hospital } \\
\text { admissions }\end{array}$ \\
\hline
\end{tabular}

ACL anterior cruciate ligament; $A U S$ Australia; ED emergency department; GP general (primary) practitioner; NZ New Zealand; SA South Africa; U under (age); UK United Kingdom; USSA University Sports South Africa

\section{Sex of Participants}

Seven studies indicated that they included males, who represented 5.7-10.5\% of hospitalisations [21-23], and $2-19 \%$ of injuries [52] [48, 52, 55]. No other information was provided on the sex of participants, although it was presumed to be only female in most studies, based on the level of competition or competition categories.

\section{Level of Competition}

Participants in the included studies were elite in five (11\%) studies [16, 26, 27, 42, 44], elite and/or sub-elite in another $11(24 \%)$ studies [17-20, 30, 33, 36, 37, 40, 41]. In $13(28 \%)$ of the studies [6, 13, 21, 22, 28, 32, 34, $39,45-47,50,51]$ participants were not elite, and in the final $17(37 \%)$ studies [3, 8, 9, 23-25, 29, 31, 35, 38, 43, $48,49,52-55]$ participants were from a wide range of competition levels.

\section{Data Collection Period}

Of the prospective studies, six (30\%) were conducted over less than one week (tournaments) [17-20, 36, 37]. Two (10\%) of these studies were over part of a season
$[34,35]$, seven $(35 \%)$ were over one season $[13,21,25$, $27,29,30,33]$, and five (25\%) were over two or more seasons [22, 26, 28, 31, 32]. The retrospective studies (n =9) investigated injuries in the previous two weeks [39], previous season [41], previous year [45], during televised games [44] or all previous injuries [17, 38, 40, 42] [43]. The hospital/clinic/insurance records analyses were conducted over 10 months $(n=1)$ [16], 1 year $(n=6)[3,23$, $46,50,51,54], 2-3$ years $(n=2)[8,9]$ or 4 or more years $(n=8)[6,24,47-49,52,53,55]$.

\section{Data Collection Methods}

In the prospective studies, physiotherapists diagnosed and recorded injuries in 10 (50\%) studies [13, 17, 20, 25-29, 33, 37], although in three of these studies, only elite players' data were provided by physiotherapists, with non-elite players' data provided by selfreport $[25,33,37]$. Five $(25 \%)$ of the prospective studies [21, 22, 30, 32] used only self-report data, and training injuries were often dependent on player notification to a therapist [29]. In the other prospective studies, physiotherapists or students/trainers/first 
aiders/coaches provided injury treatment and records of injury [18, 19, 31, 34, 36]. In the retrospective studies, eight (89\%) studies [17, 38-43, 45] relied exclusively on self-report of injuries while one study [44] used medical diagnosis of anterior cruciate ligament (ACL) injuries. Health professionals provided the diagnoses and injury records for all the hospital/ clinic/insurance records studies.

\section{Sites and Severity of Injury Data Collected}

In the prospective studies, 11 (55\%) studies [18, 19, 21, $22,26,27,31,32,34,36,37$ ] investigated all injuries. Two (10\%) studies investigated all moderate-severe injuries (injury required immediate treatment and resulted in some disability) $[13,28]$. Three $(15 \%)$ studies focused on lower limb and back injuries [17, 20,29], two lower limb only [30,35], one lower body non-contact injuries [33] and one only ankle injuries [25]. Of the retrospective studies, four (44\%) investigated all injuries [39, 4143]. One study investigated recurrent ankle injuries [38], one lower limb and back [17], one lower limb [40], one knee and ankle overuse [45] and one ACL injuries [44]. In the hospital/clinic/insurance records studies, 12 (71\%) investigated all injuries $[3,6,8,9,16,23,24,46,48,52$, $54,55]$, two $(12 \%)$ focused on fractures $[50,51]$, one on ACL injuries [47], one on Achilles ruptures [49] and one on dental claims [53].

\section{Results Regarding Injury Characteristics}

Table 2 provides a summary of the injury definitions used, player exposure and injury rates, the primary sites and types of injuries, and the key findings of the studies.

\section{Injury Definitions}

Only one prospective study [26] did not provide a clear injury definition. Nine (45\%) prospective $[13,18,19,21$, $22,28,29,32,36]$ and three $(33 \%)$ retrospective $[38,39$, 44] studies included seeking or receiving treatment in their injury definition. Four (20\%) prospective studies $[25,30,33,37]$ and one retrospective study [43] included time loss from training or competition in their definition, with a further three studies using time loss to determine injury severity $[18,19,45]$.

\section{Player Exposure to Netball Matches or Training}

Match and training exposure were reported in eight (57\%) of the season competition prospective studies [21, $22,25,30-33,35]$. Match only exposure was reported in three $(21 \%)$ of these studies $[13,28,29]$ and all $(100 \%)$ of the tournament studies [17-20, 36, 37].

\section{Injury Rates}

A variety of methods were used to report injury rates and incidence. Of the prospective studies, 11 (55\%) reported injury incidence per 1000 player hours (PH) [18, 19, 21, 22, 25, 32-37]. Six (30\%) studies reported injury rates per player [26, 27, 36], per 1000 players [36], per player/match $[13,28]$ or per player/season [31]. Four of the season competition prospective studies reported injury rates of 11.3 to $14 / 1000 \mathrm{PH}[21,22]$ [32, 34] for all injuries. Rates of $1.74 / 1000 \mathrm{PH}$ were reported for ankle sprains [25], 11.29/1000PH for lower limb injuries [33] and 5.9/1000PH for ankle and knee injuries [35]. Greater injury rates for matches $(17 \times)$ compared with training were reported by Attenborough et al. [25] and in elite (2.7x) compared with sub-elite players [33]. Ten (50\%) of the prospective studies [13, 17-21, 28-30,33] and seven $(78 \%)$ of the retrospective studies $[17,40-45]$ reported the percentage (\%) of players injured. The \% of injured players in regular season play ranged from 5.2$20 \%$ in recreational players to $30.6-37.5 \%$ in predominantly elite players. Injury proportions in tournaments ranged from 15 to $25 \%$. The hospital/clinic/insurance records studies reported netball injuries as a \% of all presenting injuries studied $(n=6)[6,23,46,47,50,51]$, relative to population $(n=4)[9,23,24,49]$ or estimated playing population $(n=5)$ [3, 23, 48, 54, 55], or simply stated the number of cases $(n=3)[8,52,53]$.

\section{Comparison of Injury Rates in Matches, Tournaments, Training and Warm-up}

Hopper et al. [29] reported no injuries during training, Attenborough et al. [25] reported nine ankle sprains during matches compared with two during training, and Chong et al. [47] reported three ACL injuries during matches and one during training. Langeveld et al. [18] found that $95 \%$ of injuries occurred in matches, $3 \%$ in warm-up and $2 \%$ in practice and Joseph et al. [3] reported that $92 \%$ of injuries occurred in matches. Hume [23] also commented that injuries during warm-up (3\%) and practice $(1.5 \%)$ were low compared with matches. Langeveld et al. [18] noted that injury rates were higher in tournaments compared with regular season competition.

\section{Injury Sites}

Forty-three studies (96\%) provided some data on injury site in terms of body area. There were various methods of categorising body areas among the studies, some more specific (e.g. ankle sprains, Achilles injury), others more generalised (e.g. lower limb injury) (Table 2). Fifteen studies (33\% of all 46 studies) were limited to specific body sites or regions based on the aim of their study and eight of those (17\% of all studies) were limited to a single structure or injury type, for example, ACL 
Table 2 Characteristics of injuries to netball players reported in included studies $(n=46)$

\begin{tabular}{|c|c|c|c|c|}
\hline Study & Injury definition & Exposure $^{a}$ & $\begin{array}{l}\text { Injury rate or } \\
\text { proportion of } \\
\text { injuries }\end{array}$ & Injury s \\
\hline \multicolumn{5}{|c|}{ Prospective season competition } \\
\hline $\begin{array}{l}\text { Attenborough } \\
\text { et al. } 2017 \text { [25] }\end{array}$ & Ankle injury time loss $>1 d$ & $\begin{array}{l}\text { Matches and } \\
\text { training } \\
\text { Matches } \\
1333 \mathrm{~h} \\
\text { Training } \\
4992 \mathrm{~h} \\
\text { Total } 6325 \mathrm{~h}\end{array}$ & $\begin{array}{l}6.75 \text { sprains/ } \\
1000 \mathrm{PH} \\
\text { matches } \\
0.40 \text { sprains/ } \\
1000 \mathrm{PH} \text { training } \\
1.74 \text { sprains/ } \\
1000 \mathrm{PH} \text { total }\end{array}$ & Ankle \\
\hline
\end{tabular}

Type and/or Key findings ${ }^{\mathbf{b}}$
severity of
injury

Elphinston Not stated

et al. 2006 [26]
Not reported

\section{player at \\ baseline}

0.2 injuries/

player after

intervention

\author{
Pre v. Post \\ intervention: \\ Ankle-27 vs \\ $25 \%$ \\ Knee-14 vs \\ $50 \%$ \\ Lower back \\ -18 vs $0 \%$ \\ Shoulder-32 \\ vs $25 \%$ \\ Neck-9 vs $0 \%$
}

Ferreira et al. Injury sustained during match 2010 [27]
Not reported or training
Ankle-39.1\%

Knee-28.3\%

Cervical-8,7\%
Minor-35\% Moderate$56.6 \%$ Severe- $8.7 \%$
Finch et al. 2002 [22]
Injury led to reduced sporting activity or treatment or adverse economic/social effects
$68 \%$ training and matches< $2.5 \mathrm{~h}$ per week
Injury required treatment or resulted in some disability Minor complaints not included
Match only $5.2 \%$ or $50.83 /$
1000 players/
match
11.3 (95\%Cl 9.8- Ankle-53.8\% 12.9)/1000 PH total

Knee-27.7\%

Finger/thumb $26.2 \%$

Lower back$16.9 \%$ Head/face $6.2 \%$
Muscle strain38.8\% Contusion$24.8 \%$ Ligament sprain-61.2\% Broken bone8.5\% Moderate-60$70 \%$

Ankle- $58.2 \%$ Knee- $15.2 \%$ Hand-13.3\% Other-13.3\%
New-71.3\% Recurrent$28.7 \%$
11 sprains: 9 during matches; 2 during training Odds ratio for ankle sprain $4.04 \times$ higher $(p=0.04)$ if reach distance in post-medial direction of SEBT $<77.5 \%$ of leg length; trends for relationships between ankle joint laxity, static and dynamic balance and injury risk; no relationships with previous sprain, vertical jump performances or perceived ankle instability

Implementation of a multidisciplinary integrated sports science and sports medicine approach addressing fundamental functional problems of players resulted in a marked reduction in the number of injuries. Screening and evaluation of players functional performance followed by individualised technical training and conditioning were implemented resulting in a marked reduction (550\%) in injuries. No training or overuse injuries after intervention.

$35 \%$ of injuries minor; $56.5 \%$ moderate (miss 8-21 d); 8.7\% severe.

$52.2 \%$ of injuries associated with incorrect landing. Inadequate physical or motor abilities (biomechanical deviations, excess body fat, poor balance, and limited explosive power) were identified and may have contributed to injuries.

\section{Ligament sprains/tears and} ankle injuries more common in netball than many other sports.

Most injuries (60-70\%) were classified as moderate severity and required treatment by a health professional.

Injury rate in netball lower than AFL, field hockey and basketball. 94.3\% of netball players were female.

Injury incidence higher in highest grades for both Junior (47\%) and Senior (35\%) players; more hand injuries in 
Table 2 Characteristics of injuries to netball players reported in included studies $(n=46)$ (Continued)

\begin{tabular}{lllll}
\hline Study Injury definition & Exposure $^{\mathbf{a}}$ & $\begin{array}{l}\text { Injury rate or } \\
\text { proportion of } \\
\text { injuries }\end{array}$ & $\begin{array}{l}\text { Injury site } \\
\text { injus findings }\end{array}$ & $\begin{array}{l}\text { Type and/or } \\
\text { severity of } \\
\text { injury }\end{array}$ \\
\hline
\end{tabular}

junior players; More new injuries occurred in 1st quarter of matches; More recurrent injuries occurred in 2nd quarter of matches; No association between player position and injury; Knee injury resulted in greater disability than other injuries; Most severe injuries were due to slips or falls.

\begin{abstract}
Hopper et al. Injury required treatment or 1995 [28] resulted in some disability
\end{abstract} Minor complaints not included

Match only $5.4 \%$ or $0.054 /$ player/match Ankle-84.3\% Knee- $8.3 \%$ Hand- $2.8 \%$ Other-4.6\%

Hopper et al. 1995 [29]

Injury required treatment or resulted in some disability Minor complaints not included

Match only $30.6 \%$ of players injured

Maulder et al. Time loss training or game No history lower limb injury in previous 6 months
Match and

training injured
$37.5 \%$ of players
McKay et al. 1996 [31]
Bodily harm resulting in stopped play, substitution, or obvious disability

\section{Ankle-22.2\% Ankle sprain- \\ Calf-22.2\% \\ Knee-22.2\% \\ Achilles-11.1\% \\ Adductor- \\ $11.1 \%$ \\ Shin-11.2\%}

Match and

training
17.3 injuries/

1000players/

season Major or severe injuries $1 / 250$ games

Ligaments-

$81 \%$

Fracture-11\%

Soft tissue-8\%

Ankle injuries mostly lateral ligament sprain Knee injuries included $3 \mathrm{ACL}$ 
Table 2 Characteristics of injuries to netball players reported in included studies ( $n=46)$ (Continued)

\begin{tabular}{|c|c|c|c|c|c|c|}
\hline Study & Injury definition & Exposure $^{a}$ & $\begin{array}{l}\text { Injury rate or } \\
\text { proportion of } \\
\text { injuries }\end{array}$ & Injury site & $\begin{array}{l}\text { Type and/or } \\
\text { severity of } \\
\text { injury }\end{array}$ & Key findings ${ }^{b}$ \\
\hline & & & & $3.9 \%$ & & $\begin{array}{l}\text { poor landings }(15.1 \%) \text {, and } \\
\text { being hit by the ball }(18.2 \%) \\
\text { were the main injury inciting } \\
\text { events. }\end{array}$ \\
\hline $\begin{array}{l}\text { McManus } \\
\text { et al. } 2006 \text { [32] }\end{array}$ & $\begin{array}{l}\text { Bodily harm resulting in } \\
\text { decrease in sports activity, } \\
\text { required medical advice or } \\
\text { treatment, or had adverse } \\
\text { economic or social } \\
\text { consequences; Recurrences } \\
\text { counted as original only; No } \\
\text { injury in previous } 3 \text { months }\end{array}$ & $\begin{array}{l}\text { Match and } \\
\text { training }\end{array}$ & $14 / 1000 \mathrm{PH}$ & $\begin{array}{l}\text { Ankle-32\% } \\
\text { Knee-17\% } \\
\text { Hand/wrist- } \\
15 \% \\
\text { Back-9\% }\end{array}$ & $\begin{array}{l}\text { Sprains-34\% } \\
\text { Strains }-22 \% \\
\text { Bruising-15\% }\end{array}$ & $\begin{array}{l}\text { Risk factors for injury: no } \\
\text { warm-up (IRR 1.11) and not } \\
\text { being open to new ideas (IRR } \\
\text { 1.04). } \\
\text { Protective factors regarding } \\
\text { injury: training } \geq 4 \text { h/week (IRR } \\
0.66 \text { ) and having no injury in } \\
\text { the previous } 12 \text { months (IRR } \\
0.58 \text { ). }\end{array}$ \\
\hline $\begin{array}{l}\text { Pickering } \\
\text { Rodriguez } \\
\text { et al. } 2017 \text { [33] }\end{array}$ & $\begin{array}{l}\text { Non-contact bodily harm to } \\
\text { soft tissues of lower limb and } \\
\text { time loss } \geq 1 \text { game }\end{array}$ & $\begin{array}{l}\text { Match and } \\
\text { training }\end{array}$ & $\begin{array}{l}34 \% \text { injured } \\
11.29 \text { lower } \\
\text { body injuries/ } \\
1000 \mathrm{PH} \\
\text { Elite } 19.35 / 1000 \\
\mathrm{PH} \\
\text { Sub-elite } 7.13 / \\
1000 \mathrm{PH}\end{array}$ & $\begin{array}{l}\text { Calf-33\% } \\
\text { Ankle-25\% } \\
\text { Knee-17\% }\end{array}$ & $\begin{array}{l}\text { Included strains, } \\
\text { sprains, tears, } \\
\text { avulsion } \\
\text { fractures, } \\
\text { impingement, } \\
\text { inflammation }\end{array}$ & $\begin{array}{l}\text { Higher stiffness in soleus and } \\
\text { Achilles increased non-contact } \\
\text { lower limb injury risk in elite } \\
\text { players only. }\end{array}$ \\
\hline $\begin{array}{l}\text { Pringle et al. } \\
1998 \text { [34] }\end{array}$ & $\begin{array}{l}\text { Bodily harm that impaired a } \\
\text { player's performance }\end{array}$ & Unclear & $\begin{array}{l}\text { 13/1000 PH } \\
\text { Moderate } \\
\text { injuries 6/1000 } \\
\text { PH }\end{array}$ & $\begin{array}{l}\text { Ankle } \\
\text { Wrist } \\
\text { Fingers }\end{array}$ & $\begin{array}{l}\text { Sprains most } \\
\text { common } \\
8 \text { minor injuries } \\
7 \text { moderate } \\
\text { injuries }\end{array}$ & $\begin{array}{l}\text { Incidence of injury in children } \\
\text { playing sport is low. }\end{array}$ \\
\hline $\begin{array}{l}\text { Stevenson } \\
\text { et al. } 2000 \text { [21] }\end{array}$ & $\begin{array}{l}\text { Bodily harm resulting in } \\
\text { decrease in sports activity, } \\
\text { required medical advice or } \\
\text { treatment, or had adverse } \\
\text { economic or social } \\
\text { consequences }\end{array}$ & $\begin{array}{l}\text { Match and } \\
\text { training }\end{array}$ & $\begin{array}{l}12.1 / 1000 \mathrm{PH} \\
20 \% \text { of players } \\
\text { had an injury } \\
\text { requiring } \\
\text { medical } \\
\text { attention }\end{array}$ & - & $\begin{array}{l}37 \% \text { injuries } \\
\text { were ligament } \\
\text { strains or tears } \\
\text { Moderate- } \\
\text { severe-20\% }\end{array}$ & $\begin{array}{l}\text { Injured players slightly older } \\
\text { than non-injured. } \\
\text { Highest rate of injuries occurs } \\
\text { in first month of season-IR } \\
28.9 / 1000 \text { player hours. } \\
20 \% \text { of netball injuries were } \\
\text { graded as moderate-severe } \\
\text { but few required hospital } \\
\text { admission. } \\
93 \% \text { of players were female. }\end{array}$ \\
\hline $\begin{array}{l}\text { Zulkarnain } \\
\text { et al. } 2019 \text { [35] }\end{array}$ & $\begin{array}{l}\text { Self-reported lower limb } \\
\text { injuries during training or } \\
\text { competition }\end{array}$ & $\begin{array}{l}77 \mathrm{~h} \text { training } \\
32 \mathrm{~h} \\
\text { matches }\end{array}$ & $\begin{array}{l}\text { Overall 5.9/1000 } \\
\text { PH } \\
\text { Training only IG } \\
\text { 5.0/1000 PH } \\
\text { Training only CG } \\
\text { 9.7/1000 PH }\end{array}$ & $\begin{array}{l}\text { Ankle } 65 \% \\
\text { Knee } 35 \%\end{array}$ & $\begin{array}{l}\text { Sprain } 71 \% \\
\text { Strain } 29 \%\end{array}$ & $\begin{array}{l}\text { Intervention reduced training } \\
\text { injuries but not match injuries } \\
\text { or re-injuries. } \\
\text { Number needed to treat to } \\
\text { reduce lower limb training } \\
\text { injuries was } 3 .\end{array}$ \\
\hline \multicolumn{7}{|c|}{ Prospective tournaments } \\
\hline $\begin{array}{l}\text { Hopper and } \\
\text { Elliot } 1993[17]\end{array}$ & $\begin{array}{l}\text { A disability to lower limb or } \\
\text { back that caused pain or some } \\
\text { degree of dysfunction. }\end{array}$ & $\begin{array}{l}\text { Tournament } \\
\text { matches }\end{array}$ & $\begin{array}{l}23 \% \text { of players } \\
\text { sustained lower } \\
\text { limb or back } \\
\text { injuries }\end{array}$ & $\begin{array}{l}\text { Ankle-36.6\% } \\
\text { Foot-11.5\% } \\
\text { Calf/shin- } \\
19.2 \% \\
\text { Knee-17.3\% } \\
\text { Thigh-1.9\% } \\
\text { Back-13.5\% }\end{array}$ & $\begin{array}{l}\text { Sprain-40.5\% } \\
\text { ACL-3.8\% } \\
\text { Strain-1.9\% } \\
\text { Tendinitis- } \\
11.5 \% \\
\text { Fracture-3.8\% } \\
\text { Spine-9.6\% } \\
\text { Joints-11.5\% } \\
\text { Haematoma- } \\
7.7 \% \\
\text { Medical } \\
\text { issues-7.7\% } \\
\text { Grade 1-71\% } \\
\text { Grade 2-15.4\% } \\
\text { Grade 3-13.5\% }\end{array}$ & $\begin{array}{l}32.5 \% \text { of players had an injury } \\
\text { at start of tournament-Open } \\
44 \% \text {; U21 27\%; U16 27\%. } \\
\text { New injuries 63.5\%; Recurrent } \\
36.5 \% \text {. } \\
\text { Severity: Grade } 171 \% \text { of } \\
\text { injuries, Grade } 215.4 \% \text {, Grade } \\
3 \text { or fracture } 13.5 \% \text {. } \\
\text { Common overuse injuries } \\
\text { were shin soreness (38\%); } \\
\text { retropatellar pain (24\%; Older } \\
\text { > Younger). } \\
\text { No significant differences in } \\
\text { perceived landing techniques } \\
\text { between injured and } \\
\text { uninjured players. } \\
\text { No relationships identified } \\
\text { between types of injury and } \\
\text { podiatric variables. }\end{array}$ \\
\hline
\end{tabular}


Table 2 Characteristics of injuries to netball players reported in included studies ( $n=46)$ (Continued)

\begin{tabular}{ll}
\hline Study & Injury definition \\
\hline Smyth et al. $\quad \begin{array}{l}\text { Any injury requiring } \\
\text { physiotherapy attention. }\end{array}$ \\
& $\begin{array}{l}\text { Sport incapacity injuries- } \\
\text { where player missed part of } \\
\text { match or reported reduced } \\
\text { capacity. }\end{array}$
\end{tabular}

\section{Retrospective}

Attenborough Recurrent: two or more sprains et al. 2016 [38] to the same ankle

Finch et al. 2006 [39] njury: any injury associated with participation Significant injury: required treatment, interfered with daily activities and/or adverse effects on participation or performance in subsequent activity
Hopper and A disability to lower limb or Elliot 1993 [17] back that caused pain or some degree of dysfunction.

$\begin{array}{ll}\text { Exposure }^{\mathrm{a}} & \begin{array}{l}\text { Injury rate or Injury site } \\ \text { proportion of } \\ \text { injuries }\end{array}\end{array}$

Type and/or Key findings ${ }^{b}$
severity of
injury

on cement courts than synthetic surfaces; $80 \%$ knee injuries and $89 \%$ serious injuries occurred on cement courts.

$\begin{array}{lll}9 \times 40 \text { min } & \text { Injury incidence } & \text { Ankle 25\% } \\ \text { matches per } & 89.4 / 1000 \mathrm{PH} & \text { Foot } 12.6 \% \\ \text { team } & \text { U19> U17 IRR } & \text { Trunk 16.5\% } \\ & 1.64 & \text { Lower leg 9.7\% } \\ & \text { Sports } & \text { Head \& neck } \\ & \text { incapacity 19.1/ } & 5.8 \% \\ & \text { Wrist \& hand } \\ & & 5.8 \% \\ & & \text { Pelvic area 4.9\% } \\ & & \text { Shoulder 4.9\% } \\ & & \text { Thigh 2.9\% }\end{array}$

Ankle sprains $13.6 \%$

Foot blisters

$10.7 \%$

Lumbar pain

9.7\%

Incapacity $21 \%$ of injuries: Ankle

$\mathrm{ACL}$ rupture $n=$ 3 Concussion $n=$ New > recurrent (IRR 9.3)

Trauma 51 Overuse 42 (IRR 1.24)

$72 \%$ previous ankle sprain $47 \%$ recurrent ankle sprain

Participation 19 injuries/10, included in 000 population survey

51 injuries/1000

All injuries and

Any significant

injuries participants 24 significant injuries/1000 participants in netball Participation rate for netball 389/10,000 population

$23 \%$ of all players sustained lower limb/low back injuries

Right ankle $66.7 \%$

Left ankle

$49.6 \%$

Right knee

25.9\%

Left knee 17.1\%

Retropatellar

pain $23.7 \%$

Shin soreness

38.2\%

Back pain 33\%

$90 \%>$ lower limb injuries during career
Main body region injured was lower limb. Joint injuries were $33 \%$ of all injuries.

Main circumstances of injury were collision (16.5\%), contested landings (12.6\%), and running (15.5\%).

$27 \%$ of players arrived at tournament with an existing injury or illness.
Sprains

(1)

An


Table 2 Characteristics of injuries to netball players reported in included studies $(n=46)$ (Continued)

\begin{tabular}{|c|c|c|c|c|c|c|}
\hline Study & Injury definition & Exposure $^{a}$ & $\begin{array}{l}\text { Injury rate or } \\
\text { proportion of } \\
\text { injuries }\end{array}$ & Injury site & $\begin{array}{l}\text { Type and/or } \\
\text { severity of } \\
\text { injury }\end{array}$ & Key findings ${ }^{b}$ \\
\hline & & & & $\begin{array}{l}\text { Both knee } 6 \% \\
\text { One knee 13\% } \\
\text { Shin 18\% } \\
\text { Retropatellar } \\
11 \%\end{array}$ & $\begin{array}{l}3 \text { injuries }-22 \% \\
4 \text { injuries-9\% } \\
5-6 \text { injuries- } \\
5 \%\end{array}$ & $\begin{array}{l}\text { lower limb injury. } \\
\text { Bilateral ankle injuries } \\
\text { common whereas as unilateral } \\
\text { knee injuries more common. } \\
\text { Pronating foot types with rear } \\
\text { foot abnormalities were the } \\
\text { most common foot types and } \\
\text { the types most associated } \\
\text { with lower limb injuries. }\end{array}$ \\
\hline $\begin{array}{l}\text { Pillay et al. } \\
2012 \text { [41] }\end{array}$ & $\begin{array}{l}\text { Any physical complaint that } \\
\text { occurred during a match or } \\
\text { training, irrespective of } \\
\text { medical attention or time loss }\end{array}$ & $\begin{array}{l}\text { Matches 2/ } \\
\text { week } \\
\text { Netball } \\
\text { training 3.7/ } \\
\text { week } \\
\text { Gym training } \\
\text { 3.4/week }\end{array}$ & $\begin{array}{l}1.9 \text { injuries/ } \\
\text { player/season } \\
61.8 \% \text { of players } \\
\text { injured/season } \\
\text { National } 84.3 \% \\
\text { injured } \\
\text { State } 59.2 \% \\
\text { injured } \\
\text { Club 54.5\% } \\
\text { injured }\end{array}$ & $\begin{array}{l}\text { Ankle } 37.5 \% \\
\text { Knee 28.6\% } \\
\text { Other leg 10.6\% } \\
\text { Upper limb } \\
12.7 \% \\
\text { Other 6.7\% }\end{array}$ & $\begin{array}{l}\text { Mild-40\% } \\
\text { Moderate-16\% } \\
\text { Severe-44\% } \\
33 \% \text { miss } \geq 1 \\
\text { game }\end{array}$ & $\begin{array}{l}\text { State (provincial) players } \\
\text { sustained more ankle injuries } \\
(56.7 \%) \text { than club (22.5\%) or } \\
\text { national (20.8\%) players. State } \\
\text { players had more knee injuries } \\
(61 \%) \text { than national (26\%) or } \\
\text { club (13\%) players. } \\
\text { Injuries attributed to landing } \\
\text { (ankle } 29 \% \text {, knee } 19 \%) \text { and } \\
\text { tripping (ankle } 8 \% \text {, knee } 6 \%) \text {. } \\
\text { Centre (28\%) and goal attack } \\
\text { (19\%) tended to have higher } \\
\text { knee injury rates than other } \\
\text { positions. }\end{array}$ \\
\hline $\begin{array}{l}\text { Singh et al. } \\
2013 \text { [42] }\end{array}$ & $\begin{array}{l}\text { Trauma resulting in cessation } \\
\text { of play }\end{array}$ & $\begin{array}{l}62.7 \% \\
\text { netball } \\
\text { training }>6 \\
\text { h/week } \\
91.5 \% \text { fitness } \\
\text { training with } \\
71 \%>3 \mathrm{~h} / \\
\text { week }\end{array}$ & $\begin{array}{l}68 \% \text { of } 59 \\
\text { players injured } \\
29 \% \text { one injury } \\
27 \% \text { two injuries } \\
12 \% \text { three } \\
\text { injuries }\end{array}$ & $\begin{array}{l}\text { Ankle } 55.8 \% \\
\text { Knee } 41.9 \% \\
\text { Wrist 2.3\% } \\
23.7 \% \text { had } \\
\text { recurrent } \\
\text { injuries }\end{array}$ & $\begin{array}{l}\text { Ankle- } \\
\text { ligament } \\
\text { sprains/Achilles } \\
\text { Knee-ACL, } \\
\text { meniscus, } \\
\text { patella tendon } \\
23.7 \% \text { recurrent } \\
\text { ankle or knee } \\
\text { injuries }\end{array}$ & $\begin{array}{l}\text { Ankle-71\% lateral ligament } \\
\text { sprains; 21\% Achilles } \\
\text { tendonitis; Knee-22\% ACL; } \\
\text { 17\% meniscal; 33\% patella } \\
\text { tendon; knee injuries in U21 } \\
\text { and Senior players (not U16); } \\
23.7 \% \text { injuries recurring. } \\
\text { Injuries attributed to poor } \\
\text { landing (52.5\%), collisions } \\
\text { (27.5\%), playing surface } \\
(17.5 \%) \text {, repetitive movements } \\
(2.5 \%) \text {. 23.7\% of injuries } \\
\text { recurring (to ankle or knee). } \\
\text { More injuries to wing attack } \\
(31.3 \%) \text { and goal defence } \\
\text { (23.5\%) positions. } \\
\text { 10.2\% reported a foot } \\
\text { abnormality; } 60 \% \text { wore } \\
\text { medium-cut shoes, } 37.3 \% \\
\text { wore low-cut shoes }\end{array}$ \\
\hline $\begin{array}{l}\text { Smith et al. } \\
2005 \text { [43] }\end{array}$ & $\begin{array}{l}\text { Trauma causing player to } \\
\text { cease play and miss } \geq 1 \text { game }\end{array}$ & & $\begin{array}{l}35 \% \text { a netball } \\
\text { injury }\end{array}$ & $\begin{array}{l}\text { Ankle } 42 \% \\
\text { Knee } 27 \% \\
\text { Finger } 15 \% \\
\text { Other } 16 \%\end{array}$ & Any & $\begin{array}{l}\text { Non-hypermobile }(n=70) \\
21 \% \text { injured; moderately } \\
\text { hypermobile }(n=51) 37 \% \\
\text { injured; hypermobile }(n=79) \\
43 \% \text { injured; players in more } \\
\text { hypermobile groups } 3 \times \text { more } \\
\text { likely to be injured. } \\
\text { Risk of injury increased 1.5x } \\
\text { with each year of netball } \\
\text { played. }\end{array}$ \\
\hline $\begin{array}{l}\text { Stuelcken } \\
\text { et al. } 2016 \text { [44] }\end{array}$ & Documented $\mathrm{ACL}$ injuries & & $\begin{array}{l}\text { Wing attack } \\
62.5 \% \\
\text { Centre 19\% } \\
\text { Goal shooter } \\
12.5 \% \\
\text { Wing defence } \\
6 \%\end{array}$ & $\begin{array}{l}\text { Left knee } n= \\
10 \\
\text { Right knee } n= \\
6\end{array}$ & $\begin{array}{l}\mathrm{ACL} \text { injuries } \\
\text { only }\end{array}$ & $\begin{array}{l}\text { Court position: attacking third } \\
44 \% \text {; centre third 37\%; } \\
\text { defensive third 19\%. } \\
\text { Player: attacking 69\%; } \\
\text { defending 25\%; loose ball 6\%. } \\
\text { Circumstances: Landing from } \\
\text { jump } 81 \% \text { (receiving pass } \\
77 \% \text {; block/intercept 23\%); } \\
\text { repositioning 13\%, loose ball } \\
6 \% \text {; } 50 \% \text { non-contact; } 50 \% \text { in- } \\
\text { direct contact. }\end{array}$ \\
\hline
\end{tabular}


Table 2 Characteristics of injuries to netball players reported in included studies $(n=46)$ (Continued)

\begin{tabular}{ll}
\hline Study & Injury definition \\
\hline Whatman & $\begin{array}{l}\text { Overuse injuries defined as } \\
\text { et al. 2017 [45] }\end{array}$ \\
& $\begin{array}{l}\text { those without a specific } \\
\text { identifiable event responsible } \\
\text { for their onset } \\
\text { Substantial problems- } \\
\text { moderate to severe reductions } \\
\text { in or inability to perform } \\
\text { training or competition }\end{array}$
\end{tabular}

\section{Hospital, clinic or insurance records}

$\begin{array}{ll}\text { Cassell et al. } & \text { Medical treatment of netball } \\ 2003[46] & \text { injuries in injury surveillance }\end{array}$

\section{Chong et al. Female ACL injuries at hospital} 2004 [47]

Fernando et al. 2018 [9]

Netball injury presentations to $\mathrm{ED}$

Finch et al. 1998 [6]

$\begin{array}{ll}\text { Exposure }^{a} & \begin{array}{l}\text { Injury rate or Injury site } \\ \text { proportion of } \\ \text { injuries }\end{array}\end{array}$

injuries
Knee problems

$31 \%$

Substantial knee

problems $10 \%$

Ankle problems

$51 \%$

Substantial ankle

problems $24 \%$

$6.9(5.4-8.3) \%$

of sport and

recreation

injuries at ED

$6.7(5.1-8.2) \%$

of sport and

recreation injury

presentations to

General

Practitioners

4 of 13 (31\%)

female $\mathrm{ACL}$

injuries were for

netball

$>15$ years $38.7 /$

100,000

population

Females 92\%

Males 8\%
$3.7 \%$ child $/ 6.6 \%$

adult sports

injury ED

presentations

$3.3 \%$ child $/ 2.5$

adult sports

injury hospital

admissions

$14 \%$ injured

children and 8\%

injured adults

admitted to

hospital

Children $n=$ 1924

Head-5.8\%

Upper limb-

$54.4 \%$

Lower limb-

$37.3 \%$

Trunk-1.4\%

Adults $n=3098$

Head-4.9\%

Upper limb-

27.5\%

Lower limb-

63.9\%

Trunk-2.0

Other-1.8\%

Annual netball

hospitalisation

rate $1.4 / 1000$

participants/year

Fractures 0.4/

1000

Knee/leg37.4\% Ankle/foot-
Other-1.1\%

\section{Type and/or \\ severity of}

injury

Most injuries in first or fourth quarters of games.

Overuse knee and ankle problems

Relationships between overuse knee and ankle injuries and movement competency, landing technique, ankle range of motion and jump performance investigated. No relationships identified.

Any

Netball was ranked 4th in emergency department presentations and general practitioner presentations after Australian football, cycling and basketball.

ACL only

All reported as non-contact landing injuries; $n=3$ playing for school (mean age 15 years), $n=1$ playing for club ( 25 years); $n=3$ injured during match, $n=1$ injured during training.

$>4$ years $n=7777$ presentations; $5-14$ years 2250 (29\%); 15-24 years 3151 (41\%), $25-44$ years $2139(28 \%),>45$ years $193(2 \%)$. Netball ranked 13 th out of 20 sports for ED presentations relative to participation.

2009 [48]
Netball injuries at hospital
Lacer/

abrasion-3.8\%

Haematoma-

$14.9 \%$

Inflammation-

$10.7 \%$

Fracture-22.0\%

Sprain/strain$43.5 \%$

Other-4.8\%

Lacer/

abrasion-3.4\%

Haematoma-

$9.3 \%$

Inflammation-

$10.0 \%$

Fracture-13.3\%

Sprain/strain-

$57.5 \%$

Other-6.3\%

Both child and adult netball injuries mostly sprains, fractures and bruising/ inflammation. Upper limb injuries more common in children (54.4\%)

versus adults (27.5\%). Lower limb injuries more common in adults (63.9\%) versus child (37.3\%). Head injuries similar in children (5.8\%) and adults (5\%).

Fracture-29.5\% 88.9\% female. Sprain/strain$27.8 \%$ Fractures were most common injury, mostly forearm Muscle/ fractures, and highest in 5-14tendon-17.3\% year age group; ACL: 98\% of Dislocation- admissions for ACL rupture 
Table 2 Characteristics of injuries to netball players reported in included studies $(n=46)$ (Continued)

\begin{tabular}{|c|c|c|c|c|c|c|}
\hline Study & Injury definition & Exposure $^{a}$ & $\begin{array}{l}\text { Injury rate or } \\
\text { proportion of } \\
\text { injuries }\end{array}$ & Injury site & $\begin{array}{l}\text { Type and/or } \\
\text { severity of } \\
\text { injury }\end{array}$ & Key findings ${ }^{b}$ \\
\hline & & & $\begin{array}{l}\text { participants/year } \\
\text { ACL } 0.4 / 1000 \\
\text { participants/year }\end{array}$ & $\begin{array}{l}\text { Trunk-1.7\% } \\
\text { Head/neck- } \\
6.6 \% \\
\text { Other-6.2\% }\end{array}$ & $\begin{array}{l}10.1 \% \\
\text { Other-5.6\% }\end{array}$ & $\begin{array}{l}\text { were elective, in private } \\
\text { hospitals, in } 25-34 \text {-year age } \\
\text { group. } \\
\text { Achilles rupture: rate higher } \\
(1.7 \times) \text { for males; highest in } \\
35-44 \text {-year age group. }\end{array}$ \\
\hline $\begin{array}{l}\text { Gwynne-Jones } \\
\text { et al. } 2011 \text { [49] }\end{array}$ & $\begin{array}{l}\text { Netball Achilles injury at } \\
\text { hospital }\end{array}$ & & $\begin{array}{l}\text { Achilles ruptures } \\
24.0 / 100,000 \\
\text { population }\end{array}$ & Achilles & Ruptures & $\begin{array}{l}\text { Netball: } 24 \% \text { of all Achilles } \\
\text { injuries; } 31 \% \text { of sporting } \\
\text { Achilles injuries; } 54 \% \text { of } \\
\text { Achilles injuries in women 15- } \\
40 \text { years. }\end{array}$ \\
\hline $\begin{array}{l}\text { Hassan et al. } \\
2001[50]\end{array}$ & $\begin{array}{l}\text { Fractures occurred } \\
\text { participating in sport; resulted } \\
\text { in presentation to ED }\end{array}$ & & $\begin{array}{l}\text { Netball injuries } n \\
=54 \\
\text { Fractures }=24 \% \\
\text { of hospital } \\
\text { netball injuries }\end{array}$ & Fingers $75 \%$ & Fractures $n=13$ & $\begin{array}{l}\text { Place of netball injury: school } \\
\text { grounds } 100 \% ; \text { netball } \\
\text { accounted for } 12 \% \text { of } \\
\text { fractures in girls, } 2^{\text {nd }} \text { after } \\
\text { rollerblading. Fractures } 24 \% \text { of } \\
\text { netball injuries; } 75 \% \text { netball } \\
\text { fractures to forearm or fingers. } \\
\text { Circumstances of netball } \\
\text { injury: } 61 \% \text { struck by ball; } 23 \% \\
\text { fall; } 8 \% \text { collision; } 8 \% \text { other. }\end{array}$ \\
\hline $\begin{array}{l}\text { Hon et al. } \\
2001[51]\end{array}$ & $\begin{array}{l}\text { Sports related fractures at } \\
\text { hospital }\end{array}$ & & $\begin{array}{l}\text { Netball injuries } n \\
=3\end{array}$ & Fractures & Fractures $n=3$ & $\begin{array}{l}33 \% \text { of female sports fractures } \\
\text { due to netball. }\end{array}$ \\
\hline
\end{tabular}

Hume 1993 Presentations at hospital, ED,

[23] or sports injury clinic or Insurance claims sports fractures

\section{Netball}

hospitalisation

rate $4.3 / 100,000$

population/year

$143 / 100,000$

netball players/

year

$7.7 \%$ of sports

ED attendances

9.5\% netball

players injured/

year

$5.3 \%$ sports

insurance

claims/year

4.5-5.6\% netball

players injured/

year (Clinic data)
Hospitalisation Hospitalisation Head/Face 8.4\% Sprain/strain Upper limb $11.2 \%$ Lower limb 79\%

Emergency Dept Head/Face 2.5\% Upper limb $33.4 \%$

Lower limb $49.2 \%$

Insurance claims

Head/Face $19.7 \%$

Upper limb $12.3 \%$

Lower limb

$62.6 \%$

Sports Med

Clinic

Head/Face $4.6 \%$

Upper limb

$24.7 \%$

Lower limb

$66.2 \%$
$58.7 \%$

Fracture 20.3\%

Dislocation

$11.2 \%$

Emergency

Dept

63.7\%

Fracture 9.5\%

Contusion $7.4 \%$

Insurance

claims

Sprain/strain

$56.6 \%$

Fracture $15.1 \%$

Dental $17.0 \%$

Sports Med

Clinic

Sprain/strain

$73.1 \%$

Fracture $7.5 \%$

Graze $7.5 \%$

\section{.}

$26.2-30 \%$ of netball injuries recurrent (Clinic data). Injuries to the ankle, knee and fingers were the most prevalent; injuries to the head/face were more substantial in insurance claims data.

Sprains/strains were the most prevalent types of injury; Fractures were more prevalent in hospital/ED and insurance claims data; Dental injuries only captured in insurance claims data. Injury severity of hospitalisations: $53.1 \%$ minor, $37.8 \%$ moderate, $9.1 \%$ severe Hospitalised injuries due to: over-exertion 56.6\%; falls $29.3 \%$; struck by person or object $13.3 \%$.

Insurance claims due to: tripping/stumbling 22.6\%; being struck 17.3\%; lifting/ straining $15.5 \%$; loss of balance $14.8 \%$.

Minor injuries more likely treated as Sports Injury Clinic. Slightly more injuries in wing defence $19.4 \%$ and centre $18.7 \%$ versus $<15 \%$ other positions

Occurrences varied during warm-up (3\%); 1st half $43.3 \%$; 2nd half 44.8\%; practice $1.5 \%$ $89.5 \%$ of netball hospitalisations to females; $10.5 \%$ to males. 
Table 2 Characteristics of injuries to netball players reported in included studies ( $n=46)$ (Continued)

\begin{tabular}{|c|c|c|c|c|c|c|}
\hline Study & Injury definition & Exposure $^{a}$ & $\begin{array}{l}\text { Injury rate or } \\
\text { proportion of } \\
\text { injuries }\end{array}$ & Injury site & $\begin{array}{l}\text { Type and/or } \\
\text { severity of } \\
\text { injury }\end{array}$ & Key findings ${ }^{b}$ \\
\hline $\begin{array}{l}\text { Hume et al. } \\
1994 \text { [24] }\end{array}$ & $\begin{array}{l}\text { Presentations at hospital, ED, } \\
\text { or sports injury clinic or } \\
\text { Insurance claims }\end{array}$ & & $\begin{array}{l}89.34 / 100,000 \\
\text { population }\end{array}$ & All & $\begin{array}{l}\text { Lower extremity } \\
\text { most frequent } \\
\text { For ACC claims: } \\
\text { sprains/strains } \\
\text { dominant }\end{array}$ & $\begin{array}{l}\text { Netball 4th most injuries after } \\
\text { rugby union, rugby league } \\
\text { and soccer. }\end{array}$ \\
\hline $\begin{array}{l}\text { Joseph et al. } \\
2019 \text { [3] }\end{array}$ & $\begin{array}{l}\text { Injury resulting from trauma } \\
\text { while training for or playing } \\
\text { netball in approved } \\
\text { competition }\end{array}$ & & $\begin{array}{l}2.936 \text { claims/ } \\
1000 \\
\text { participants }\end{array}$ & $\begin{array}{l}\text { Knee } 42 \% \\
\text { Ankle } 29 \% \\
\text { Wrist } 11 \%\end{array}$ & $\begin{array}{l}\text { Sprains/ } \\
\text { ligaments 57\% } \\
\text { Fractures 15\% }\end{array}$ & $\begin{array}{l}\text { Most claims in } 18-24 \text { years } \\
\text { (25\%) and } 25-34 \text { years (30\%) } \\
\text { age groups. } \\
\text { Slightly more injuries in 2nd } \\
\text { quarter of match, but more } \\
\text { injuries in quarters 1, } 2 \text { and } 3 \\
\text { than } 4.92 \% \text { of injuries } \\
\text { occurred during matches. }\end{array}$ \\
\hline $\begin{array}{l}\text { King et al. } \\
2019 \text { [52] }\end{array}$ & $\begin{array}{l}\text { Any injury as a result of sports } \\
\text { participation assessed and } \\
\text { reported by a registered } \\
\text { health practitioner }\end{array}$ & & $\begin{array}{l}11748 \\
\text { moderate-to- } \\
\text { serious injuries } \\
9 \text { serious injuries }\end{array}$ & $\begin{array}{l}\text { Head \& neck } \\
2.4 \% \\
\text { Upper limb } \\
10.4 \% \\
\text { Lower limb } \\
\text { 82\% } \\
\text { Other } 0.6 \%\end{array}$ & $\begin{array}{l}\text { Soft tissue } \\
81.7 \% \\
\text { Fracture/ } \\
\text { dislocation } \\
16.7 \% \\
\text { Concussion/ } \\
\text { brain } 0.9 \% \\
\text { Laceration } 0.4 \% \\
\text { Dental } 0.14 \%\end{array}$ & $\begin{array}{l}\text { Main findings related to costs } \\
\text { of injuries. }\end{array}$ \\
\hline $\begin{array}{l}\text { Kirkwood et al. } \\
2019 \text { [8] }\end{array}$ & $\begin{array}{l}\text { Injury related to playing } \\
\text { netball }\end{array}$ & & 157 injuries & $\begin{array}{l}\text { Lower Limb } \\
36.4 \% \\
\text { Upper Limb } \\
22.7 \% \\
\text { Head } 2.6 \%\end{array}$ & $\begin{array}{l}\text { Fractures } 19.5 \% \\
\text { Ligament } \\
\text { damage } 2.6 \% \\
\text { Concussion } \\
0.65 \%\end{array}$ & $\begin{array}{l}\text { Only one admission to } \\
\text { hospital for a severe injury } \\
\text { related to netball. }\end{array}$ \\
\hline $\begin{array}{l}\text { Love et al. } \\
1998 \text { [53] }\end{array}$ & $\begin{array}{l}\text { New dental claims that year } \\
\text { Minor-Payment to health } \\
\text { professional for treatment; no } \\
\text { payment to claimant }\end{array}$ & & $\begin{array}{l}260 \text { netball } \\
\text { dental claims/ } \\
\text { year }\end{array}$ & Dental & Dental & $\begin{array}{l}\text { Netball one of } 45 \text { sports and } \\
\text { one of top } 10 \text { with dental } \\
\text { claims. Most dental injury } \\
\text { claims were new claims. }\end{array}$ \\
\hline $\begin{array}{l}\text { Otago et al. } \\
2007 \text { [54] }\end{array}$ & $\begin{array}{l}\text { Insurance netball injury claim } \\
\text { accepted }\end{array}$ & & $\begin{array}{l}9.49 \text { injuries/ } \\
1000 \text { players }\end{array}$ & $\begin{array}{l}\text { Lower limb- } \\
\text { 85.3\% } \\
\text { Upper limb- } \\
\text { 8.7\% } \\
\text { Spine/torso- } \\
\text { 3.1\% } \\
\text { Head/face- } \\
\text { 2.9\% }\end{array}$ & $\begin{array}{l}\text { Ankle sprain } \\
31 \% \\
\text { Knee sprain } \\
20.5 \% \\
\text { Knee } \\
\text { reconstruct } \\
13.6 \%\end{array}$ & $\begin{array}{l}\text { Injury costs: Knee } 56.9 \% \text {; ankle } \\
12.7 \% \text {; calf/Achilles } 11.8 \% \text {. } \\
\text { Recommended injury } \\
\text { prevention focus on ankle } \\
\text { ligament sprains, knee } \\
\text { ligament sprains and Achilles } \\
\text { tendon strains; focus on } \\
\text { Achilles injury should be in } \\
\text { players > } 25 \text { years } \\
\text { Injury claim rate highest in } \\
30-39-\text { year group; least in } 10- \\
14 \text {-year group; claim costs } \\
\text { highest in 25-29-year and > } \\
40 \text {-year groups; least in 10-14- } \\
\text { year group. }\end{array}$ \\
\hline $\begin{array}{l}\text { Purdam } 1987 \\
{[16]}\end{array}$ & $\begin{array}{l}\text { Treatment in physiotherapy } \\
\text { department }\end{array}$ & & $\begin{array}{l}5.25 \text { injuries/ } \\
\text { player/year }\end{array}$ & $\begin{array}{l}\text { Ankle-13.3\% } \\
\text { Knee-12.4\% } \\
\text { Lower limb- } \\
43.8 \% \\
\text { Upper limb- } \\
3.8 \%\end{array}$ & $\begin{array}{l}\text { Extrinsic-23.9\% } \\
\text { Intrinsic-26.7\% } \\
\text { Overuse-30.5\% } \\
\text { Spinal-20.0\% }\end{array}$ & $\begin{array}{l}\text { Author noted the relatively } \\
\text { high incidence of calf }(10 \%) \\
\text { and shin (12\%) problems in } \\
\text { netball players and suggested } \\
\text { the training surface may have } \\
\text { contributed. } \\
\text { Ankle taping/bracing and } \\
\text { preventative wobble board } \\
\text { program recommended but } \\
\text { identified compliance with } \\
\text { recommendations an issue. }\end{array}$ \\
\hline $\begin{array}{l}\text { Smartt et al. } \\
2009[55]\end{array}$ & Public hospital inpatients & & $\begin{array}{l}5 \text { injuries/100, } \\
000 \text { participants }\end{array}$ & $\begin{array}{l}\text { Lower leg/knee } \\
57 \% \\
\text { Forearm/ } \\
\text { elbow13\% } \\
\text { Wrist/hand 8\% }\end{array}$ & $\begin{array}{l}\text { Muscle/tendon } \\
46 \% \\
\text { Fracture } 32 \% \\
\text { Sprain/strain } 7 \%\end{array}$ & $\begin{array}{l}81 \% \text { female ( } 19 \% \text { male); injury } \\
\text { numbers peaked in } 30-34- \\
\text { year age group for males and } \\
\text { females } \\
\text { Also, a peak in female injury }\end{array}$ \\
\hline
\end{tabular}


Table 2 Characteristics of injuries to netball players reported in included studies ( $n=46$ ) (Continued)

\begin{tabular}{|c|c|c|c|c|c|c|}
\hline Study & Injury definition & Exposure $^{a}$ & $\begin{array}{l}\text { Injury rate or } \\
\text { proportion of } \\
\text { injuries }\end{array}$ & Injury site & $\begin{array}{l}\text { Type and/or } \\
\text { severity of } \\
\text { injury }\end{array}$ & Key findings ${ }^{b}$ \\
\hline & & & & Ankle/foot 6\% & & $\begin{array}{l}\text { numbers in 10-14-year age } \\
\text { group; overall injury rate } \\
\text { increased with age, with } \\
\text { highest injury rate in } 35-49- \\
\text { year age group; } 0-14 \text { years- } \\
\text { forearm fractures dominant; > } \\
14 \text { years-Achilles dominant. }\end{array}$ \\
\hline
\end{tabular}

$A C L$ anterior cruciate ligament; $A F L$ Australian Rules Football; $C$ centre; ED emergency department; GA goal attack; GD goal defence; GS goal shooter; IR injury rate; IRR incidence rate ratio; Lacer laceration; PH player hours; SEBT Star Excursion Balance Test (Munro and Herrington, 2010); WA wing attack; WD wing defence aExposure: many studies indicated whether calculations incorporating exposure were match, training or combined but few studies reported the exposure data ${ }^{b}$ Key findings: reporting injury rates was not the primary aim of all studies, so key findings may relate to risk factors, intervention effects, identifying groups with greater or less injury vulnerability

$[44,47]$, Achilles [49], ankle [25, 38], fracture [50, 51] or dental [53]. Hassan et al. [50] noted that $75 \%$ of netball fractures were to the fingers. In those studies that reported the injury site as a percentage of total netball injuries, the range of those percentages were as follows: ankle $n=19$, range 13.3 to $84.3 \%[13,16-18,22,26-30$, $32,33,36,37,40-43,48]$; knee $n=19$, range 8.3 to $50.0 \%[3,13,16-19,22,26-30,32,36,37,40-42]$. Injuries to the lower limb $n=8$, ranged from 36.4 to $85.3 \%$ $[6,8,16,20,23,31,52,54]$, and to the upper limb $n=$ 11 , ranged from 3.8 to $54.4 \%[6,8,16,18,23,31,36,41$, $48,52,54]$.

\section{Types of Injury}

Thirty studies (65.2\%) provided indications of the tissue damaged. Seven studies reported data on injury recurrence, with reports of $26.2-36.5 \%$ [13, 17, 18, 23, 36] for all injuries, 20\% for knee [28] and 35\% [28] and 47\% [25] for ankle injuries. Hume [23] and Hume and Marshall [24] used multiple categories of injury types ranging from abrasions to dental and intracranial injury types in their analyses of hospital and insurance databases related to netball injuries in New Zealand. Hume [23] noted that head/face injuries are more substantial in insurance claims data than in prospective, retrospective, hospital or clinic data and that dental injuries are primarily only captured in insurance data. Hopper et al. [13] distinguished between new and chronic injuries. Overuse injuries were reported in three studies [16, 17, 45]. Hopper and Elliot [17] found shin soreness (38\%) and retropatellar pain (24\%) were common. Purdam [16] reported $30.5 \%$ of injuries were overuse including $10 \%$ of calf and $12 \%$ of shin injuries. Whatman et al. [45] found overuse knee and ankle injuries were common in secondary school players.

Ligament sprains (ankle, knee, Achilles) [6, 17, 18, 21$25,28-38,42,54]$ and to a lesser extent muscle strains (calf, adductor) $[6,17,18,22,23,30-33,35,36,48,55]$ were the most widely reported injury types. Substantial bruises/hematomas/contusions [17, 18, 22, 28, 31, 32,
36] and lacerations/abrasions/grazes [6, 23, 31, 36] were also reported. Smyth et al. [37] reported that $10.7 \%$ of tournament players presented with foot blisters. Fractures $[6,17,18,22,23,28,33,48,50,51,55]$, dislocations $[23,48]$ and tendon ruptures $[17,37,42,44,49$, 54 ] were far less prevalent but were more evident in the hospital records that focused on more severe injuries. The first study reporting concussions related to netball was published in 2002 [22], and only three of the studies published since have reported on concussions related to netball $[8,37,52]$.

\section{Severity of Injury}

Sixteen studies (34.8\%) used descriptive categories, for example, mild, minor, moderate, severe, new, recurrent and overuse. Many authors stated that most netball injuries are minor, but the rates and definitions of minor, moderate and severe injuries varied among studies. Ferreira et al. [27] reported rates of 35\% minor, 56.5\% moderate and $8.7 \%$ severe, and Finch et al. [22] reported $60-70 \%$ of injures as moderate severity, indicating that treatment by a health professional was required. Stevenson et al. [21] indicated that $20 \%$ of netball injuries were moderate to severe but few required hospitalisation. Hopper and Elliot [17] used a grading system modified from Oakes (1981) [56] and reported 71\% of tournament injuries were Grade 1, 15.4\% Grade 2, and 13.5\% were Grade 3 which included fractures. Langeveld et al. [18] found $70 \%$ of injuries were minor (not missing a game), $11.4 \%$ resulted in missing $1-2$ games, and $2 \%$ resulted in missing 3-5 games. Hopper [13] found that knee injuries resulted in greater disability than other injuries, which was supported by Hopper et al. [29] who also found that there were more severe knee injuries than ankle injuries. Hopper et al. [28] reported that $15 \%$ of ankle and $27 \%$ of knee injuries required referral to hospital and that $10 \%$ of ankle injuries were fractures. Whatman et al. [45] reported that $10 \%$ and $24 \%$ of players had substantial knee and ankle problems, respectively. Otago et al. [54] concluded that injury costs were highest for knee injuries. 
McKay et al. [31] found there were more severe injuries in netball than basketball, and Finch et al. [39] reported that children were more likely to require treatment by a health professional than adults. The hospital/clinic/insurance records studies reported primarily on more severe injuries, although Kirkwood et al. [8] noted that there was only one admission to hospital for a severe injury related to netball in their study of 157 injuries. Finch et al. [6] reported fractures were $22 \%$ of injuries in children and $13.3 \%$ of injuries in adults. Flood et al. [48] found $29.5 \%$ of netball hospital presentations were fractures, $27.8 \%$ strains/sprains and $10.1 \%$ dislocations, which was similar to hospital and emergency department (ED) presentations reported by Hume [23]. Smartt et al. [55] found 32\% of netball hospital admissions were due to fractures. Joseph et al. [3] and Kirkwood et al. [8] found $15 \%$ and $19.5 \%$ of injuries due to fractures, respectively, and King et al. [52] reported $16.7 \%$ of injuries were due to fractures or dislocations.

\section{Circumstances of Injury}

Sixteen studies (34.8\%) reported factors associated with the circumstances of injury (COI). Hopper [13] found that most severe injuries were due to slips or falls, which was one of the main circumstances of injury identified by nine studies $[13,17,18,20,23,29,31,41,50]$. The other main circumstances were landings $[17,27-29,31$, $36,37,41,42,44,47]$, collisions/player contact [17, 18, $23,29,31,36,37,42,44,50]$, and being hit by the ball $[23,31,36,44,50]$.

\section{Timing of Occurrence of Injuries}

Ten $(21.7 \%)$ studies reported on some aspect of timing of netball injuries. Five studies (10.9\%) included data on the time and/or the quarter in the game in which injuries occurred [3, 13, 18, 23, 28]. Hopper et al. [28] reported that most injuries occurred in the 1st quarter of matches, while Hopper [13] reported that more new injuries occurred in the $1^{\text {st }}$ quarter whereas more recurrent injuries occurred in the 2nd quarter. Langeveld et al. [18] reported that most injuries occurred in the 2nd and 3rd quarters with a linear increase from the 1st to 3rd quarters. Stuelcken et al. [44] investigated ACL injuries in 16 players and found that these injuries occurred most frequently in the 1st and 4th quarters $(n=$ 6 and 4, respectively). Hume [23] found no difference between injury rates in the first (43.3\%) and second (44.8\%) halves of matches. Joseph et al. [3] found slightly more injuries in the 2nd quarter but the main trend was for there to be less injuries in the 4th quarter compared with the other three quarters. In reporting injury incidence in four sports, including netball, Stevenson et al. [21] found there was an overall elevated level of injury incidence in the first month of the season with an injury rate of 28.9 injuries per $1000 \mathrm{PH}$ compared with the season mean of 12.1 injuries per $1000 \mathrm{PH}$.

\section{Environmental and Surface Conditions}

Four studies $(8.7 \%)$ reported on playing surface in relation to injury frequency. Studies reported a lower injury incidence on synthetic surfaces compared with concrete [19], bitumen [13] and grass [13]. Pillay et al. [41] and Joseph et al. [3] stated that the most common surface on which injuries occurred was outdoor concrete, and Coetzee et al. [19] reported this was the surface associated with most (88.9\%) serious injuries. Purdam [16] also suggested that the training surface may contribute to injuries.

\section{Player Age and Injury Risk}

Fifteen studies (32.6\%) included data relating injury incidence to age. Most studies reported a higher injury incidence with increasing age $[3,9,17,21,37,39,42,43,48$, $54,55]$, one found more injuries in younger players [36] and in others it depended on the specific injuries being investigated [6, 13, 48, 54, 55]. Hopper [13] found more hand and knee injuries in junior players. Finch et al. [6] found more upper limb injuries in children (54.5\%) compared with adults $(27.5 \%)$ but more lower limb injuries in adults $(63.9 \%)$ compared with children (37.3\%). Finch et al. [39] noted that children had a lower overall injury rate compared with adults. Flood et al. [48] found forearm fractures were highest in the 5-14-year age group, ACL ruptures highest in the 25-34-year age group, and Achilles ruptures highest in the 35-44-year age group, and Otago et al. [54] stated that Achilles injuries occur primarily in those over 25 years.

\section{Competition Level and Injury Risk}

A higher injury incidence was reported in elite or higher grade players compared with lower grade players $[13,28$, $29,41]$. Hopper [13] reported that higher grade players had more injuries than lower grade players at both junior and senior levels. Pillay et al. [41] found that statelevel players had a higher incidence of ankle and knee injuries than both club level and national level players.

\section{Player Position and Injury Risk}

Seven studies reported on the specific position or a group of positions (attacking or defending) being played at the time of injury $[17,18,23,28,41,42,44]$. The player positions more likely to be injured varied with the study. Stuelcken et al. [44] reported that ACL injuries varied with court position with more injuries in the attacking third (44\%) and centre third (37\%) compared with the defensive third (19\%). Hopper and Elliot [17] also reported that more injuries (54\%) occurred when playing an attacking position. In contrast, an earlier 
study [13] reported no association between player position and injury.

\section{Other Factors Associated with Increased Injury Risk}

A number of factors were reported as increasing risk of injury. Attenborough et al. [25] reported 4.04 times greater odds of sustaining an ankle sprain during netball if a player's preseason performance on the posteriormedial direction of the Star Excursion Balance Test (SEBT) was $\leq 77.5 \%$ of their leg length. Pickering Rodriguez et al. [33] found a relationship between higher soleus and Achilles stiffness (assessed with a validated hop test on a force platform) and higher incidence of lower body injuries in elite netballers. Smith et al. [43] reported significantly increased injury incidence in junior netball players with higher levels of hypermobility. Also, having a lower limb asymmetry in turn performance > $10 \%$ was identified as increasing risk of a lower limb injury [30]. Hopper et al. [29] found that more athletic players, as evidenced by higher vertical jump and aerobic fitness, and less endomorphy, were at higher injury risk. Ferreira et al. [27] found that excess body fat, poor balance and agility, and limited explosive power may have contributed to injuries. Chronic ankle instability contributed to increased risk of recurrent ankle sprains in recreational players [38]. A lack of warm-up [32, 36] and a previous injury $[19,32]$ were also identified as increasing injury risk. Coetzee et al. [19] reported that a lack of core stability and poor utilisation of neuromuscular and proprioceptive training increased injury risk. Hume et al. [36] reported that players failed to adopt recommended injury prevention strategies, such as using wobbleboards, using ankle supports or wearing high-cut netball shoes. Further, 54.7\% reported finishing the game before seeking treatment [36]. All of these behaviours may have contributed to higher risk of injury or more severe injury. Smyth et al. [37] reported that $27 \%$ of players arrived at their tournament with an existing injury or illness.

\section{Factors Not Associated with Increased Injury Risk or Protective}

Hopper and colleagues investigated a number of podiatric variables $[17,40]$, as well as the somatotype [20] and the landing techniques of players [17], and found no relationships with injury risk. Flexibility training was also found to be of limited benefit in preventing injury [19]. Whatman et al. [45] found no relationships between movement competency, landing technique, ankle range of motion or jump performance on overuse knee and ankle injuries. McManus et al. [32] found that not having an injury in the previous 12 months and training more than four hours per week were protective against injury.

\section{Comparison of Netball Injuries with Other Sports}

A number of studies compared netball injury presentations to those of other sports. McKay et al. [31] reported that netball had 3.3 times more severe injuries compared with basketball. Finch et al. [22] found netball had a lower injury rate than Australian Rules Football (AFL), field hockey and basketball. Finch et al. [39] reported less injuries with netball compared with cricket, horse riding and soccer but more than AFL, basketball and tennis. Fernando et al. [9] compared the top 20 sport and recreational activities in terms of injury-related ED presentations; netball ranked 13th in terms of injury rate and 19th in terms of cost per presentation. Kirkwood et al. [8] found netball ranked 2nd to trampoline for sports-related ED attendances in 0-19 year-old females. Cassell et al. [46] found netball ranked 4th in sportsrelated ED and general practitioner presentations after AFL, cycling and basketball in Australia. Hume et al. [24] also found netball ranked $4^{\text {th }}$ in presentations after rugby union, rugby league and soccer in New Zealand. Hassan et al. [50] found netball was responsible for the largest percentage of fractures presenting to the ED in girls after rollerblading, and Hon et al. [51] found netball accounted for $33 \%$ of sports related fractures in females. Gwynne-Jones et al. [49] found netball accounted for $31 \%$ of all sports related Achilles injuries and $54 \%$ of all Achilles injury ruptures at hospital in females aged 1540 years. Love et al. [53] found netball was one of the top 10 sports responsible for sports-related dental insurance claims. More recently, King et al. [52] compared the moderate to serious sports-related insurance claims by females across five sports (netball, rugby union, rugby league, football, cricket) and found by far the most claims were for netball but the relative of risk of injury was lowest in netball. Mean cost per claim was 4th in netball, only higher than football for moderate to serious claims but 2 nd to rugby union in serious claims.

\section{Interventions to Reduce Injuries in Netball}

Only two studies $[26,35]$ reported on the outcomes of an injury reduction program. Elphinston et al. [26] used an integrated multidisciplinary sports science and sports medicine approach incorporating screening and evaluation of players followed by individualised technical training and conditioning to achieve a reduction from 1.3 to 0.2 injuries per player. Zulkarnian et al. [35] found that the Down to Earth safe-landing technique program reduced training injuries but not match injuries.

\section{Discussion}

This systematic review presents the first summary of the published literature on netball injuries. Forty-six studies published in 45 papers met the inclusion criteria. Twenty studies were prospective, nine were 
retrospective, and 17 were analyses of hospital/clinic records or insurance claims. Not surprisingly, all the studies were from British Commonwealth countries with most conducted in Australia, New Zealand or South Africa. Injury rates over a netball season of 11.3-14/ $1000 \mathrm{PH}$ were reported in recreational players whereas in elite players 19.35/1000PH was reported [33]. Injuries were predominantly to the lower limb, particularly the ankle, with ligament sprains the most common injury type. One study reported younger players had more injuries to the upper rather than lower limbs [6]. Severe injuries (those resulting in hospitalisation) were typically fractures, especially in children, and ACL or Achilles ruptures in adult players. There were few head injuries reported in netball. Player characteristics, such as age and level of competition, may influence injury rates. There are few data on male netball players, although the game is still played predominantly by females. Larger prospective studies would be beneficial to further improve our understanding of possible risk factors for injury and the types of injury in netball.

A number of points are clear from the studies included in this review. Firstly, $87 \%$ of the studies were conducted in Australia, New Zealand or South Africa, with very little representation from the other 73 countries who have netball organisations. Australia and New Zealand have, in recent times, been the two dominant nations in international netball competitions. This success may reflect the high proportion of these nations' young and recreational populations participating in netball. High participation incurs an associated injury impact and cost, and therefore, possible available funding from governments to research injury incidence, type and risk factors in netball.

Second, most studies included players across a wide age range with little reporting of the results by age. Children (< 16 years) were included in $92 \%$ of the database studies, $63 \%$ of the retrospective studies, but only $39 \%$ of the prospective studies. It is generally acknowledged that hospital and insurance data do not provide a complete picture of the volume or type of injuries that occur in a sport but do identify those that are the most serious [6]. Finch et al. [6] provide the most comprehensive hospital emergency department data comparing child and adult injury rates in netball. They reported children experiencing a much higher percentage of upper limb injuries (54\% vs $27.5 \%)$ and fewer lower limb injuries $(37.3 \%$ vs $63.9 \%)$, more fractures (22\% vs $13.3 \%)$ and fewer sprains/strains $(43.5 \%$ vs $57.5 \%)$ compared with adults. Only Smartt et al. [55] reported their hospital admission results across a number of age ranges. Among those < 18 years, they identified a higher injury rate in the 10 14-year group; however, most injuries occurred in those $25-39$ years with the highest number of cases in the $30-$ 34-year age group. Less serious injuries, which are the most numerous, are usually managed in other ways and at non-hospital locations. Pringle et al. [34] focused on children (6-15 years) in their prospective study and concluded that the incidence of injury in children playing netball is low. There is clearly a need to improve our understanding of less severe injury types and rates by age in netball.

Third, competition level was reported to influence injury rates, which has also been described in other sports $[57,58]$. Studies of elite players are often overrepresented relative to less competitive players in sports injury studies [59]. Elite or sub-elite players were the focus of $63 \%$ of the retrospective studies, $50 \%$ of the prospective studies but only one (8\%) of the database studies. Four studies [13, 28, 29, 41] reported that injury rates were higher in players in elite compared with lower competition levels. One limitation when comparing injury rates in elite vs recreational players is that injury data collection methods may differ with competition level, even within the same study [25, 33]. No studies have investigated whether injury rates or types vary with competition levels when elite/sub-elite players are excluded.

A number of potential risk factors for injury in netball, in addition to age and competition level, have been investigated, mostly in only one or two studies. Those reporting increased risk of injury included poor balance $[31,44]$ and agility [44], joint stiffness [40] or hypermobility [45], lower limb asymmetry [33], chronic ankle instability [35], lack of core stability [20], lack of warm-up $[39,43]$, previous injury $[20,39]$ and playing when injured [32, 43], and not adopting recommended injury prevention strategies [20,43]. Whether player position influences risk of injury is not yet clear $[16,18,19,24$, $29,37,54]$. Further studies are required to determine the impact of these factors on injury risk and whether interventions targeting these factors can reduce injuries.

The method of injury data collection used in the studies varied, with many studies using unqualified personnel, for example students or team managers, and this reporting was particularly influenced by the level of competition of the players. In the season-competition prospective studies, those conducted on recreational players only obtained their data by self-report $[21,22$, 32]. In contrast, in studies of elite players, almost all injuries were assessed and recorded by physiotherapists $[17,20,26-29]$. In studies investigating injuries across a broad range of competition levels, some were recorded by physiotherapists $[13,28,29]$ while others were selfreported or recorded by physiotherapy or sports science students or first aid staff $[18,19,25,31,36]$. In the tournament prospective studies, medical staff contributed to injury recording in two studies $[17,20]$ whereas a range 
of personnel provided the treatment or completed the injury records in the other studies $[18,19,36]$. Thus, there is uncertainty in the accuracy of injury records obtained from some of these varied methods. The method of data collection most likely to capture all injuries that occur on courts in competition (at all levels) is to have data collected on the courts at the time of play by appropriately qualified sports medicine professionals, with follow-up and specialist referral when necessary. To increase the accuracy and depth of injury data collected, future studies should ensure that all personnel collecting data are suitably qualified and trained in standardised injury reporting, and/or that each injury is reviewed by a qualified health professional.

Injury rates were reported using a number of different metrics and some studies focused on particular types of injury only; consequently, consolidating the findings on injury rates is limited. Some of that inconsistency may be related to the fact that 13 of the articles included in this review were published before $2000[6,13,16,17,20$, $23,24,28,29,31,34,40,53]$, and two before 1990 [13, 16]. Reporting injuries by exposure $(/ 1000 \mathrm{PH})$ was limited in the studies included in this review but data from four prospective studies [21, 22, 32, 34] in recreational players provided consistent values of 11.3 to 14 injuries/ $1000 \mathrm{PH}$. Injury rates in tournaments or in more elite players appear to be higher. Pickering Rodriguez et al. [33] reported injury rates of $19.35 / 1000 \mathrm{PH}$ for elite players compared with only $7.13 / 1000 \mathrm{PH}$ for sub-elite players. Higher injury risk at higher levels of competition appears to be consistent with several other sports (e.g. tennis, soccer, and rugby union $15 \mathrm{~s}$ ) [60-62].

Future studies should aim to use standardised methods, such as those outlined by Fuller et al. [63] in their consensus statement for the collection of injury data in rugby union, to further build on the existing evidence provided by the studies in this review. This consensus statement provides operational definitions for injury, severity, injury recurrence, match and training exposure, as well as recommended methods for collecting and classifying injury data. The development of a consensus statement by the International Netball Federation would assist in this process.

Although the proportion of injuries to each body region varied among studies, most netball injuries in those over 15 years were to the lower limb, particularly the ankle and knee. Ankle injuries were far more frequent than knee injuries with the exception of Maulder et al. [30]. There were reports of injuries to other parts of the lower limb [17, 18, 30, 33, 36, 40, 41] and back [17, 20, $22,26]$; the upper limb, particularly the hand $[13,18,28$, $32,34,43,50,55]$, wrist $[18,32,34,42,55]$ and forearm [55]; and relatively smaller numbers of injuries to the head, face or neck [22, 23, 26, 27, 31, 36, 48, 53, 54] although those to the head or face, including dental injuries, were evident in insurance claims [23, 53]. Interestingly, while only four studies included in this review $[8,22,37,52]$ provided any data on concussion injuries in netball, a report on sports-related concussion identified that the rate of concussion in netball has been increasing [64]. Netball Australia has developed a concussion policy [65] based on the Concussion in Sport Australia Position Statement [66] and the Consensus Statement of the International Conference on Concussion in Sport [67]. This concussion policy may be justified as 'collision' is a frequently cited circumstance of injury in netball, and females may be more vulnerable to and take longer to recover from a concussion [66].

It was not possible to determine the extent to which there are multiple injuries associated with a single injury incident. For example, it is possible that slips, trips, falls or collisions could result in injuries to both upper and lower limbs and possibly the head. It is not clear in the prospective and retrospective studies whether all injuries are recorded or only the most severe or memorable injuries. Similarly, in hospital records and insurance claims, it is likely only the most severe injury is recorded.

There has been limited standardisation of reporting of COI. In the Coetzee et al. [19] study, $60.8 \%$ of injuries were attributed to 'physical contact' and Hon and Kock [51] also used this terminology, as did Pringle et al. [34] and Hopper et al. [29]. 'Collision', a similar term, was used by Singh et al. [42] and McKay et al. [31]. Landing 'incorrectly' and 'awkwardly' were used by a number of authors but without a clear definition of a 'correct' landing. A more specific system of describing COI may lead to further associations with specific injuries and, as a result, enable equipment, coaching and training strategies to minimise these injuries. This should include intrinsic and extrinsic factors as well as differentiating between acute and overuse injuries [16]. It should also be noted that many studies used questionnaires to gather this information from players, which introduces recall bias and player opinion about what their COI might have been. Players may need training in the terms to use to describe these circumstances to improve consistency of description. Stuelcken et al. [44] was the only study to review video footage of games, providing the opportunity to assess possible mechanisms of ACL rupture, in addition to COI. Injury risk is likely a multi-factorial phenomenon; however, if the circumstances associated with injuries are reported in a detailed, standardised manner, then further studies can examine these more closely. These findings could provide the basis for strategies to be developed for modifiable factors, such as neuromuscular control in ACL injuries in a range of sports [68] and implemented in training for the purpose of reducing the incidence of those injuries. 
Currently, most recreational netball competitions are played outdoors on concrete/asphalt 'all weather' courts, and so players are exposed to a variety of weather conditions that may influence the type and incidence of injuries [3]. Elite competitions are also often played on these courts, as well as indoors on sprung timber courts, which may produce different injury profiles. Indoor competitions mostly play on synthetic surfaces over concrete bases, again possibly affecting the pattern of injury and frequency. Playing surface has been shown to influence injury rates in netball [3] and other sports [69-71]. Although concrete playing surfaces may be a risk factor for injury in netball $[3,16]$, data on playing surfaces were limited in the studies in this review and so the impact of playing surface type on injury incidence needs further investigation.

Training data should be reported in future studies to clarify which practices associated with training are associated with injury risk. This should include the type, duration, intensity and frequency of training activities, as well as any injuries that may occur during training. These studies may then be able to identify training practices associated with high injury risk, or the effect of changed training loads on the incidence of injury during games, enabling coaches and trainers to modify training practices and reduce injury risk.

The main strengths of this review are the comprehensiveness of the search, the good agreement between reviewers for inclusion of studies, the stratification of the studies into categories and the rigour of data extraction. The main limitations are those that relate to the quality and extent of reporting in the included studies, particularly differences in injury definitions, limited or lack of clarity regarding the use of health professionals to collect data or verify injury diagnosis in recreational players, reliance on self-report data in many studies, and limited reporting of injuries by age or sex.

Recommendations for research and practice are 1) for data on recreational players to incorporate a diagnosis by a qualified health professional; 2) for netball injury data to be collected by people trained in injury reporting and ideally stored in a centralised national database; 3 ) to report data by age group, especially among those < 18 years of age, such as (a) $<10$ years, (b) $\geq 10 \leq 15$ years and (c) $>15 \leq 17$ years; 4) to provide data on male players separately if included; 5) to provide more detail on the types of head injuries sustained by netball players, including the extent and severity of concussion injuries; 6) to provide greater documentation of injuries relative to training and/or match load; and 7) to provide stronger evidence of risk factors, particularly in relation to circumstances and mechanisms for netball injuries that can be targeted by prevention strategies and provide teachable suggestions for coaches. This would improve the data available to netball clubs, organisations and sports medicine personnel working with netball communities, and enable them to provide appropriate resources and equipment to manage injuries and reduce injury risk in this large, varied population of netball players.

\section{Conclusions}

This review found that most netball injuries are to the lower limb, particularly the ankle, and that injuries to the upper limb have a higher rate in those $<16$ years old. Severe injuries are fractures in younger players and ACL and Achilles injuries in adults. Injury rates appear higher in elite players than recreational players. Factors often associated with injury include circumstances such as landings, slips/trips/falls, collisions/player contact and being hit by the ball. Further studies should be directed towards recreational netball, reporting on injury incidence in the under 15-year population and utilising high-quality, standardised methods and criteria. Specific injury diagnosis and a better understanding of the link with circumstances of injury would provide more meaningful data for developing prevention strategies. Further classification of data into acute/ recurrent/chronic and timing of injuries may provide links to elements in training and games which increase or decrease injury risk. Studies identifying successful injury prevention strategies are also needed.

\section{Supplementary Information}

The online version contains supplementary material available at https://doi. org/10.1186/s40798-020-00290-7.

\section{Additional file 1}

\section{Abbreviations}

ACL: Anterior cruciate ligament; AFL: Australian Football League;

AUS: Australia; C: Centre; COI: Circumstances of injury; ED: Emergency department; GA: Goal attack; GD: Goal defence; GS: Goal shooter; GP: General practitioner; INF: International Netball Federation; IR: Injury rate; IRR: Incident rate ratio; NIH: National Institutes of Health; NSIC: National Sports Information Centre; NZ: New Zealand; PH: Player hours; SA: South Africa; SEBT: Star Excursion Balance Test; TRIPP: Translating Research into Injury Practice Prevention; U: Under; UK: United Kingdom; USSA: University Sports South Africa; WA: Wing attack; WD: Wing defence

\section{Acknowledgements \\ Not applicable.}

\section{Authors' Contributions}

CD-conducted the search, screened articles and extracted data, and drafted the manuscript. SS—designed the search, screening and data extraction processes, and edited the manuscript. IW-screened articles, contributed to the quality of assessment of studies and developed figures, and provided feedback on the manuscript. SRV - updated the search and screening of articles, provided thorough review of the manuscript and final preparation of the figures. RC - designed the search, screening and data extraction processes, extracted data and development of the tables, revised and edited the manuscript. The author(s) read and approved the final manuscript. 


\section{Funding}

No funding supported the development of this manuscript.

\section{Availability of Data and Materials}

All data generated or analysed during this study are included in this published article and its supplementary information files.

\section{Ethics Approval and Consent to Participate}

Statements regarding ethics approval and consent to participate were included in all the papers in this review.

\section{Consent for Publication}

Not applicable.

\section{Competing Interests}

Christopher Downs, Suzanne J. Snodgrass, Ishanka Weerasekara, Sarah R. Valkenborghs and Robin Callister declare that they have no conflicts of interest relevant to the content of this review.

\section{Author details}

${ }^{1}$ School of Health Sciences, University of Newcastle, Newcastle, NSW Australia. ${ }^{2}$ Priority Research Centre for Physical Activity and Nutrition, University of Newcastle, Newcastle, NSW, Australia. ${ }^{3}$ Department of Physiotherapy, University of Peradeniya, Peradeniya, Central Province, Sri Lanka. ${ }^{4}$ University of Newcastle, School of Biomedical Science and Pharmacy, Newcastle, NSW, Australia.

\section{Received: 17 August 2020 Accepted: 1 December 2020} Published online: 06 January 2021

\section{References}

1. International Netball Federation. International Netball Federation Website [https://netball.sport/]. 2019 [updated 01/10/2019.

2. All Australia Netball Association. All Australia Netball Association. 2015.

3. Joseph C, Naughton G, Antcliff A. Australian netball injuries in 2016: An overview of insurance data. J Sci Med Sport. 2019;22(12):1304-8.

4. Egger G. Sport injury in Australia: Causes, cost and prevention. A report to the National Better Health Program. 1990.

5. Fong DT, Hong Y, Chan LK, Yung PS, Chan KM. A systematic review on ankle injury and ankle sprain in sports. Sports Medicine. 2007;37(1):73-94.

6. Finch C, Valuri G, Ozanne-Smith J. Sport and active recreation injuries in Australia: evidence from emergency department presentations. British Journal of Sports Medicine. 1998;32(3):220-5

7. Everison R, Leeds M, Wicks S. Sports injuries to children. Kidsafe WA. 2010; No 18.

8. Kirkwood G, Hughes TC, Pollock AM. Results on sports-related injuries in children from NHS emergency care dataset Oxfordshire pilot: an ecologica study. Journal of the Royal Society of Medicine. 2019;112(3):109-18.

9. Fernando DT, Berecki-Gisolf J, Finch CF. Sports injuries in Victoria, 2012-13 to 2014-15: evidence from emergency department records. Med J Aust. 2018, 208(6):255-60.

10. Netball Australia. [Available from: www.netball.com.au.]

11. Finch C. A new framework for research leading to sports injury reduction. Journal of Science and Medicine in Sport. 2006;9(1-2):3-9.

12. Moher D, Liberati A, Tetzlaff J, Altman DG, Group P. Preferred reporting items for systematic reviews and meta-analyses: the PRISMA statement. PLOS medicine. 2009:6(7):e1000097.

13. Hopper D. A survey of netball injuries and conditions related to these injuries. Australian Journal of Physiotherapy. 1986;32(4):231-9.

14. McHugh ML. Interrater reliability: The kappa statistic. Biochemia Medica (Zagreb). 2012;22(3):276-82.

15. National Heart LaBI. Study Quality Assessment Tools [Available from: www nhlbi.nih.gov/health-topics/study-quality-assessment-tools.

16. Purdam C. A survey of netball and basketball injuries. Excel. 1987:3(3):9-11

17. Hopper D, Elliott B. Lower limb and back injury patterns of elite netball players. Sports Medicine. 1993;16(2):148-62

18. Langeveld E, Coetzee FF, Holtzhausen LJ. Epidemiology of injuries in elite South African netball players. South African Journal for Research in Sport, Physical Education \& Recreation. 2012;34(2):83-93.
19. Coetzee D, Langeveld E, Holtzhausen L. Training habits, training surface and injuries among South African netball players. South African Journal fo Research in Sport, Physical Education \& Recreation. 2014;36(3):39-49.

20. Hopper DM. Somatotype in high performance female netball players may influence player position and the incidence of lower limb and back injuries. British Journal of Sports Medicine. 1997;31(3):197-9.

21. Stevenson MR, Hamer P, Finch CF, Elliot B, Kresnow M. Sport, age, and sex specific incidence of sports injuries in Western Australia. British Journal of Sports Medicine. 2000;34(3):188-94.

22. Finch C, Da Costa A, Stevenson M, Hamer P, Elliott B. Sports injury experiences from the Western Australian Sports Injury Cohort Study. Aust N Z J Public Health. 2002;26(5):462-7

23. Hume PA. Netball injuries in New Zealand. New Zealand Journal of Sports Medicine. 1993;21(2):27-31

24. Hume PA, Marshall SW. Sports injuries in New Zealand: exploratory analyses. New Zealand Journal of Sports Medicine. 1994;22(2):18-22.

25. Attenborough AS, Sinclair PJ, Sharp T, Greene A, Stuelcken M, Smith RM, et al. The identification of risk factors for ankle sprains sustained during netball participation. Physical Therapy in Sport. 2017:23:31-6.

26. Elphinston J, Hardman SL. Effect of an integrated functional stability program on injury rates in an international netball squad. Journal of Science \& Medicine in Sport. 2006;9(1-2):169-76.

27. Ferreira MA, Spamer EJ. Biomechanical, anthropometrical and physical profile of elite university netball players and the relationship to musculoskeletal injuries. South African Journal for Research in Sport, Physical Education \& Recreation. 2010;32(1):57-67.

28. Hopper D, Elliott B, Lalor J. A descriptive epidemiology of netball injuries during competition: a five year study. British Journal of Sports Medicine. 1995:29(4):223-8.

29. Hopper DM, Hopper JL, Elliott BC. Do selected kinanthropometric and performance variables predict injuries in female netball players? I Sports Sci. 1995:13(3):213-22.

30. Maulder PS. Dominant limb asymmetry associated with prospective injury occurence. South African Journal for Research in Sport, Physical Education \& Recreation. 2013;35(1):121-31.

31. McKay GD, Payne WR, Goldie PA, Oakes BW, Stanley JJ. A comparison of the injuries sustained by female basketball and netball players. Australian Journal of Science \& Medicine in Sport. 1996;28(1):12-7.

32. McManus A, Stevenson MR, Finch CF. Incidence and risk factors for injury in non-elite netball. Journal of Science \& Medicine in Sport. 2006:9(1-2):119-24.

33. Pickering Rodriguez EC, Watsford ML, Bower RG, Murphy AJ. The relationship between lower body stiffness and injury incidence in female netballers. Sports Biomechanics. 2017;16(3):361-73.

34. Pringle RG, McNair P, Stanley S. Incidence of sporting injury in New Zealand youths aged 6-15years. British Journal of Sports Medicine. 1998;32(1):49-52.

35. Jaafar Z, Khairullina K. The pilot study on Down to Earth (D2E) injury prevention program among varsity netball players. Gazzetta Medica Italiana Archivio per le Scienze Mediche. 2019;178.

36. Hume PA, Steele JR. A preliminary investigation of injury prevention strategies in Netball: are players heeding the advice? Journal of Science \& Medicine in Sport. 2000;3(4):406-13.

37. Smyth EA, Piromalli L, Antcliff A, Newman P, Waddington G, Weissensteiner JR, et al. A prospective study of health problems at the 2018 17/ $\mathrm{U}$ and 19/U Australian National Netball Championships with comparison of surveillance methodology. J Sci Med Sport. 2019.

38. Attenborough AS, Sinclair PJ, Sharp T, Greene A, Stuelcken M, Smith RM, et al. A snapshot of chronic ankle instability in a cohort of netball players. Journal of Science \& Medicine in Sport. 2016;19(5):379-83.

39. Finch $C$, Cassell E. The public health impact of injury during sport and active recreation. Journal of Science \& Medicine in Sport. 2006;9(6):490-7.

40. Hopper D, Bryant A, Elliott B. Foot types and lower limb injuries in elite netball players. J Am Podiatr Med Assoc. 1994;84(7):355-62.

41. Pillay T, Frantz JM. Injury prevalence of netball players in South Africa: the need for injury prevention. South African Journal of Physiotherapy. 2012 68(3):7-10.

42. Singh P, Mansingh A, Palmer W, Williams EW. Injuries in elite Jamaican netballers. West Indian Medical Journal. 2013:62(2):118-21.

43. Smith R, Damodaran AK, Swaminathan S, Campbell R, Barnsley L. Hypermobility and sports injuries in junior netball players. British Journal of Sports Medicine. 2005;39(9):628-31. 
44. Stuelcken MC, Mellifont DB, Gorman AD, Sayers MG. Mechanisms of anterior cruciate ligament injuries in elite women's netball: a systematic video analysis. J Sports Sci. 2016;34(16):1516-22.

45. Whatman C, Reid D. Movement quality, physical performance and prevalence of overuse injuries in secondary school netball players. New Zealand J Sports Med. 2017:44:1.

46. Cassell EPF, C.F.; Stathakis,V.Z. Epidemiology of medically treated sport and active recreation injuries in the Latrobe Valley, Victoria, Australia. Br J Sports Med. 2003;37:405-409

47. Chong RW, Tan JL. Rising trend of anterior cruciate ligament injuries in females in a regional hospital. Annals of the Academy of Medicine, Singapore. 2004;33(3):298-301.

48. Flood L, Harrison JE. Epidemiology of basketball and netball injuries that resulted in hospital admission in Australia, 2000-2004. Medical Journal of Australia. 2009;190(2):87-90.

49. Gwynne-Jones DP, Sims M, Handcock D. Epidemiology and outcomes of acute Achilles tendon rupture with operative or nonoperative treatment using an identical functional bracing protocol. Foot \& Ankle International. 2011;32(4):337-43.

50. Hassan I, Dorani BJ. Sports related fractures in children in north east England. Emergency Medicine Journal. 2001:18(3):167-71.

51. Hon WH, Kock SH. Sports related fractures: A review of 113 cases. J Orthop Surg. 2001;9(1):35-8.

52. King D, Hume PA, Hardaker N, Cummins C, Gissane C, Clark T. Sports-related injuries in New Zealand: National Insurance (Accident Compensation Corporation) claims for five sporting codes from 2012 to 2016. British Journal of Sports Medicine. 2019:53(16):1026-33.

53. Love RM, Carman N, Carmichael S, MacFadyen E. Sport-related dental injury claims to the New Zealand Accident Rehabilitation \& Compensation Insurance Corporation, 1993-1996: analysis of the 10 most common sports, excluding rugby union. N Z Dent J. 1998;94(418):146-9.

54. Otago $L$, Peake $J$. The role of insurance data in setting priorities for netball injury prevention strategies. Journal of Science \& Medicine in Sport. 2007; 10(2):105-9.

55. Smartt $P$, Chalmers D. Obstructing the goal? Hospitalisation for netball injury in New Zealand 2000-2005. New Zealand Medical Journal. 2009; 122(1288):62-75

56. Oakes BW. Acute soft tissue injuries: nature and management. Aust Fam Physician. 1981;10(7 Suppl):3-16.

57. Clifton DR, Koldenhoven RM, Hertel J, Onate JA, Dompier TP, Kerr ZY. Epidemiological patterns of ankle sprains in youth, high school and collegiate football. Journal of Sports Medicine. 2017;45(2):417-25.

58. Barber Foss KD, Le Cara E, McCambridge T, Hinton R, Kushner A, Myer GD. Epidemiology of injury in men's lacrosse: injury prevention implications for competition level, type of play, and player position. Physician \& Sports Medicine. 2017:45(3):224-33.

59. Yeomans C, Kenny IC, Cahaln R, Warrington GD, Harrison AJ, Hayes K, et al. The Incidence of injury in amateur male rugby union: A systematic review and meta-analysis. Sports Medicine. 2018:48:837-48.

60. Pluim BM, Staal JB, Windler GE, Jayanthi N. Tennis injuries: occurrence, aetiology, and prevention. British Journal of Sports Medicine. 2006;40(5):415-23.

61. Klein C, Henke T, Platen P. Injuries in football (soccer) - a systematic review of epidemiology and aetiological aspects. German Journal of Exercise and Sport Research. 2018;48(3):309-22.

62. King D, Hume P, Cummins C, Pearce A, Clark T, Foskett A, et al. Match and training injuries in women's rugby union: A systematic review of published studies. Sports Medicine. 2019;49(10):1559-74.

63. Fuller CWMGM, Bagate C, Bahr R, Brooks JHM, Donson H, Kemp SPT, McCrory P, McIntosh AS, Meeuwisse WH, Quarrie KL, Raftery M, Wiley P. Consensus statement on injury definitions and data collection procedures for studies of injuries in rugby union. Br J Sports Med. 2007;41(5):328-31.

64. Finch CF, Clapperton AJ, McCrory P. Increasing incidence of hospitalisation for sport-related concussion in Victoria, Australia. Medical journal of Australia. 2013;198(8):427-30.

65. Armstrong S. Netball Australia Concussion Policy; 2018.

66. Elkington L, Manzanero S, Hughes D. Concussion in Sport Australia Position Statement; 2019.

67. McCrory P, Meeuwisse W, Dvorak J, Mark Aubry M, Bailes J, Broglio S, et al. Consensus statement on concussion in sport-the 5 (th) international conference on concussion in sport held in Berlin, October 2016. British Journal of Sports Medicine. 2017;51:838-47.
68. Hewett TE, Ford KR, Hoogenboom BJ, Myer GD. Understanding and preventing acl injuries: current biomechanical and epidemiologic considerations - update 2010. North American Journal of Sports Physical Therapy. 2010;5(4):234-51.

69. Lanzetti RM, Lupariello D, Venditto T, Rota P, Guzzini M, Vadalà A, et al. The influence of playing surface on injury risk in Italian elite rugby players. Muscles, Ligaments and Tendons Journal. 2017;7(1):180-5.

70. Pasanen K, Parkkari J, Rossi L, Kannus P. Artificial playing surface increases the injury risk in pivoting indoor sports: a prospective one-season follow-up study in Finnish female floorball. British Journal of Sports Medicine. 2008;42: 194-7.

71. Mears AC, Osei-Owusu P, Harland AR, Owen A, Roberts JR. Perceived links between playing surfaces and injury: A worldwide study of elite association football players. Sports Medicine - Open. 2018;4:40.

\section{Publisher's Note}

Springer Nature remains neutral with regard to jurisdictional claims in published maps and institutional affiliations.

\section{Submit your manuscript to a SpringerOpen ${ }^{\circ}$ journal and benefit from:}

- Convenient online submission

- Rigorous peer review

- Open access: articles freely available online

- High visibility within the field

- Retaining the copyright to your article

Submit your next manuscript at $\boldsymbol{\nabla}$ springeropen.com 